\title{
Macronutrient status of UK groundwater: nitrogen, phosphorus and organic carbon
}

M E Stuart and D J Lapworth

\begin{abstract}
Groundwater is a large, slowly changing pool of the macronutrients nitrogen (N), phosphorus (P) and dissolved organic carbon (DOC), with impacts on receptors, surface waters, dependent wetlands and coastal marine ecosystems. Sources of $\mathrm{N}$ to groundwater include fertilisers, animal wastes and septic effluents. $\mathrm{N}$ species are well-quantified in groundwater and $\mathrm{NO}_{3}-\mathrm{N}$ has a wide range of median values $(0$ $12 \mathrm{mg} / \mathrm{L}$ ). The highest concentrations are in the Chalk of East Anglia and Humberside and the PermoTriassic Sandstone (PTS) of Staffordshire. The highest concentrations of $\mathrm{NH}_{4}-\mathrm{N}$ are found in confined aquifers. N concentrations have increased with time peaking during the 1980s. Changes in practice have led to the reduction observed in rapidly-responding aquifers. For the Chalk, where the unsaturated zone is thick, improvements may not be seen for decades. P is less well-characterised in UK groundwater reflecting the lack of historical interest in groundwater P, although it can be significant in some aquifer matrices. Groundwater P concentrations are elevated in sandstone formations compared to other lithology and highest in the PTS of the Midlands and northern England (median values $>50 \mu \mathrm{g} / \mathrm{L}$ ). Overall half of the aquifers studied in the UK have median TDP $>50 \mu \mathrm{g} / \mathrm{L}$, with values of up to $100 \mu \mathrm{g} / \mathrm{L}$ under some urban areas, such as Manchester and Liverpool as well as the Lee Valley. P concentrations in arable areas are variable (20-100 $\mu \mathrm{g} / \mathrm{L})$, whereas under semi-natural conditions they are lower (20-50 $\mu \mathrm{g} / \mathrm{L})$. There is little information on $\mathrm{P}$ trends in groundwater. Most DOC is derived from soils, playing an important part in redox processes. The aquifer matrix can contain high OC and contribute significantly to groundwater DOC. Median values range between 0.4 and $9 \mathrm{mg} / \mathrm{L}$, but rarely exceed $5 \mathrm{mg} / \mathrm{L}$, except in the Chalk of Yorkshire and Humberside and PTS of Liverpool which have long legacies of anthropogenic pollution.
\end{abstract}




\section{Introduction}

During recent decades, pools and fluxes of nitrogen (N), phosphorus (P) and carbon (C), in UK ecosystems have been transformed (Galloway et al., 2008; Vitousek et al., 1997) by the spread and fertiliser-based intensification of agriculture (Jenkinson, 2001), by atmospheric pollution (Fowler et al., 2005; Goulding et al., 1998), and now potentially by climate change (Stuart et al., 2011; Watts et al., 2015). Many terrestrial ecosystems that were previously nearly-closed with respect to $\mathrm{N}$ and $\mathrm{P}$ now permit considerable export of these nutrients (Galloway et al., 2008; Smil, 2000; Withers et al., 2001), leading to eutrophication and acidification of surface waters (Bennett et al., 2001). Carbon cycling has been affected by agricultural practices (Bellamy et al., 2005) and, in semi-natural systems (Magnani et al., 2007), through changes in net primary productivity and carbon storage brought about by $\mathrm{N}$ deposition (Townsend et al., 1996; Waldrop et al., 2004). The groundwater pool is an important, albeit slowly changing, component of the cycles of $\mathrm{N}$, $\mathrm{P}$ and $\mathrm{C}$, and in turn impacts on receptors such as surface water (Holman et al., 2010; Holman et al., 2008b) and dependent wetlands (Krause et al., 2007).

Nitrate has been recognised as an important groundwater contaminant for several decades, particularly for drinking water. The 1980 European Directive (EEC/80/778) setting the $50 \mathrm{mg} / \mathrm{L}$ limit was promulgated in the UK member states in 1989 (The Water Supply (Water Quality) Regulations 1989). Currently many groundwater abstractions do not meet this limit and water utilities have to control nitrate concentrations by blending or treatment. In contrast, P and dissolved organic carbon (DOC) have not been regarded as significant components of groundwater chemistry in the past and many studies have not reported these parameters. Phosphorus was generally considered to be relatively immobile in groundwater and DOC is a poorly characterised measurement. Additionally transport by the particulate phase is less important in many aquifers compared to surface water, however colloidal P can be a significant component of total P in the Chalk hyporheic zone and springs (e.g. Lapworth et al., 2011; Lapworth et al., 2013)

The implementation of the Water Framework Directive (2000/60/EC) has changed the way many groundwater components are regarded as the importance of groundwater contribution to surface water must be taken into account. This has been shown to be important for both $\mathrm{N}$ and P (Bowes et al., 2009; Smith et al., 2009) and also has important controls on the temporal changes in DOC quality and bioavailability (Lapworth et al., 2009). Groundwater is now routinely monitored by the UK environmental agencies for a wide range of parameters which now include $\mathrm{P}$ species and DOC, as well as $\mathrm{N}$ species. However, our understanding of the distribution of these elements in groundwater still remains limited in some areas.

The objective of this paper is to collate and assess available data on concentrations and trends of N, C and $\mathrm{P}$ and the controls on these within the context of groundwater in the UK. The comprehensive analysis of published studies covered in this paper informs the development of a conceptual frame work for understanding macronutrient sources and fate in UK groundwater systems. This builds on the outputs of baseline studies of quality in the UK but focusses on anthropogenic and well as natural water quality and includes a review of trends. Information is provided which will be useful for calibrating and validating future national scale macronutrient modelling, such as linking macronutrient transport between the 
terrestrial and the coastal marine environments. A comparison will be made with studies from other Northern European countries with similar climatic and land use conditions.

\section{Nitrogen}

\subsection{Sources of nitrogen in groundwater}

There are a multitude of anthropogenic sources of nitrate to ground waters. Nitrogen undergoes a complex series of biochemical, chemical, and physical reactions in soils and waters, and thus the source of nitrate in groundwaters is often difficult or impossible to ascertain with any degree of certainty. Soils contain a pool of organic $\mathrm{N}$ and the conversion of this insoluble organic $\mathrm{N}$ to soluble low molecular weight dissolved organic nitrogen (DON) represents a constraint to N mobility (Jones et al., 2004). Although the export of dissolved organic nitrogen (DON) into the groundwater has been recognized for more than 100 year, it is often ignored when total $\mathrm{N}$ budgets are constructed (Van Kessel et al., 2009).

The main anthropogenic sources of $\mathrm{N}$ to groundwater are thought to be commercial fertilisers, animal wastes and septic systems. For England and Wales, Chilton et al. (1996) attempted to quantify the input from a wider range of possible sources, including point-sources. These included sewer and mains leakage, highway drainage, recreational grassland, intensive livestock rearing, landfills, airfield de-icing, groundwater-surface water interactions and unsewered sanitation.

The pollutants that contribute to nitrogen deposition derive mainly from nitrogen oxides and ammonia emissions. In the atmosphere nitrogen oxides are transformed to a range of secondary pollutants, including nitric acid $\left(\mathrm{HNO}_{3}\right)$, nitrate and organic compounds, such as peroxyacetyl nitrate (PAN), while ammonia is transformed to ammonium $\left(\mathrm{NH}_{4}^{+}\right)$. Both the primary and secondary pollutants may be removed by wet deposition (scavenging of gases and aerosols by precipitation) and by dry deposition (Fowler et al., 1989; Hornung et al., 1995).

There are few studies that have investigated nitrogen containing compounds in aquifer matrices; these include undegraded proteinaceous material as well as humic substances. Tryptophan-like (protein) compounds have been detected in a number of UK groundwaters indicating anthropogenic sources of contamination and rapid pathways in the subsurface (Khamis et al., 2015; Lapworth et al., 2009; Lapworth et al., 2008a).

\subsection{Nitrogen speciation in groundwater}

Nitrogen is present in groundwater in the form of a number of dissolved species: nitrate, nitrite ammonia and DON. The inorganic species are largely dependent on the redox condition of the water with nitrate being stable under oxidising conditions and ammonia and nitrite being metastable under reducing conditions. DON has not commonly been analysed for in groundwater, but may form a significant component, certainly in the Chalk (Peach et al., 2006) and in upland catchments (Lapworth et al., 2008b). 


\subsection{Nitrogen fate and transport in groundwater}

The nitrogen cycle contains a number of both biological and abiotic processes involving compounds in the gas, liquid and solid phases. Denitrification is the most important mechanism for the removal of nitrate from the biosphere and from water. The presence of biodegradable DOC is essential (West and Chilton, 1997). When dissolved oxygen is present, degradation of DOC is performed by aerobic bacteria that use oxygen as the terminal electron acceptor for respiration. As this becomes depleted, reduction of other electron acceptors becomes energetically favourable. Facultative anaerobic bacteria can use nitrate as an electron acceptor. As nitrate is depleted, reduction reactions may proceed using other terminal electron acceptors including manganese and iron oxides and sulphate (Edmunds et al., 1982). The organisms that contribute tend to be ubiquitous in surface water, soil and groundwater (Beauchamp et al., 1989) and found at great depths in aquifers (Francis et al., 1989). In general, the absence of oxygen and the presence of organic carbon, reduced sulphur or iron facilitate denitrification.

During denitrification nitrate is converted by a series of microbial reduction reactions via nitrite, nitric oxide and nitrous oxide to mainly nitrogen gas (Brady and Weil, 2002). At low $\mathrm{pH}$ the proportion of residual nitrous oxide increases and the overall rate decreases. Nitrate can also be reduced to nitrite and nitrous oxide gas by abiotic reactions; however, these are minor relative to biological denitrification. Dissimulatory nitrate reduction to ammonia can also take place.

Nitrate is mobile in groundwater and conventionally assumed to be broadly conservative in oxic groundwater with metastable intermediary species. A study of two British aquifers using presence of intermediary species and excess $\mathrm{N}_{2}$ showed relatively little denitrification in the unsaturated zone (Gale et al., 1994). Denitrification can also be substantiated using a mass-balance approach on repeated unsaturated zone core data (Kinniburgh et al., 1999) or by looking at redox changes along a flow line (Edmunds et al., 1982). Microbiological evidence or denitrification potential can also be used. A role for till deposits has been postulated for Chalk in East Anglia. Foster et al. (1985) found denitrifying bacteria in till and the 1960s tritium peak preserved but absence of nitrate. Feast et al. (1998) found isotopic evidence of denitrification in the overlying Till deposits on the Chalk.

The Lincolnshire Limestone has been the subject of a number of denitrification studies. Groundwater within the outcrop area of the aquifer in eastern England is characterized by high ( $>11.3 \mathrm{mg} \mathrm{NO}_{3}-\mathrm{N} / \mathrm{L}$ ) nitrate concentrations, whereas in the confined zone c. $15 \mathrm{~km}$ further east, nitrate concentrations are low or undetected (Hiscock et al., 2011). Bishop and Lloyd (1990) did not find significant evidence from hydrochemical and isotopic modelling. Using stable isotopes, Hiscock et al. (2011) assessed the organic carbon substrate utilization rates as between $0.07 \mathrm{mg}$ and $0.13 \mathrm{mg} / \mathrm{L} /$ day and compared this with the available pool. This provided an estimated eventual limit of 200 years. Overall, Rivett et al. (2007) judge denitrification in the unsaturated zone and in unconfined aquifers to be insignificant in decreasing the nitrate load.

Ammonium is strongly sorbed on mineral surfaces and is relatively stable in reducing conditions and attenuation in groundwater is predominantly due to cation exchange and/or nitrification processes (Buss et al., 2004). Ammonium attenuation is highly sensitive to the clay mineralogy and pore size of the strata, 
the availability of oxygen and the chemical composition of the contaminated fluid. Nitrification can be important at the margins of contaminated groundwater plumes but is limited by oxygen solubility. Ammonia can also be converted to nitrogen gas by anaerobic oxidation (anammox) processes, more widely recognised in the marine environment (Kartal et al., 2007).

DON can comprise a significant proportion of the total $\mathrm{N}$ load in some circumstances, up to $90 \%$ in forested glacial outwash in Canada with concentrations increased by anthropogenic impacts (Kroeger et al., 2006). Lapworth et al. (2008b) also found DON was the most abundant form of dissolved $\mathrm{N}$ in both soils and groundwaters in a moorland catchment, accounting for between 47 and $72 \%$ in shallow groundwater samples and up to $80 \%$ in deeper groundwaters.

A number of studies have found that natural attenuation at the groundwater-surface water interface is a significant control on observed river nitrate concentrations (Allen et al., 2010; Lapworth et al., 2011; Pretty et al., 2006; Smith et al., 2009). Lapworth et al. (2011) showed that ecologically significant P concentrations (20-30 $\mu \mathrm{g} / \mathrm{L})$ are present in the hyporheic zone in dissolved and colloidal forms.

\subsection{N concentrations in UK groundwater: results and discussion}

\subsubsection{Baseline study}

Baseline $\mathrm{N}$ concentrations have been measured for a range of aquifers over England, Wales and Scotland as part of BGS-EA-SEPA funded research. For $\mathrm{N}$ species, samples were analysed by automated colorimetry and nitrate, nitrite and ammonia were generally measured. In a few cases TON and organic nitrogen were also quoted. A summary table of results is shown in Table 1 for each aquifer. Figures 1-3 show the data for each report area in the study ordered by increasing median concentration for nitrate, nitrite and ammonia. Shand et al. (2007) comment on the negative skew of many of the baseline nitrate cumulative frequency plots suggesting that this reflects a boundary between oxidising and reducing conditions within the dataset. It could also be interpreted as between pre-industrial baseline conditions and post-industrial contamination.

For nitrate, 4 of the 11 aquifers with the lowest median $\mathrm{NO}_{3}-\mathrm{N}$ are confined chalk and limestones, the others being Plynlimon Palaeozoic, Palaeogene sands and other sandstones Table 1). It is likely that there is a degree of confinement in the Palaeogene. Five of the 10 aquifers with the highest median $\mathrm{NO}_{3}-\mathrm{N}$ are limestones and chalk, four are Permo-Triassic sandstone and the other is the Aberdeenshire Dalradian (Figure 1).

For nitrite (Table 1) of the 15 aquifers which have median concentrations below the limit of detection 8 are in limestone and chalk, with 2 being confined, 4 are in sandstones, the remainder being in granite and Plynlimon Palaeozoic. The five highest median values are in the North Norfolk Crag and Chalk, the Carboniferous of Northern England and the Permo-Triassic sandstones of Cheshire.

In contrast, for ammonium the 12 datasets which have median values below the detection limit show no lithological relationship. From Table 1the 4 highest values are in confined chalk and limestone with the next being in the Corallian and the Palaeogene which are likely to represent confined conditions. From 
Figure 3 which does not differentiate the confined areas of aquifer, of the 11 areas with elevated ammonium concentrations, 7 are in the Permo-Triassic sandstone, 3 are limestones and the highest is in the North Norfolk Crag and Chalk.

\subsubsection{Literature data}

Rivett et al. (2007) assessed mean nitrate concentrations across England and Wales for 2006 using unpublished Environment Agency monitoring data, independent of the baseline studies summarised in this study. They show that many of the elevated occurrences coincide with major aquifer outcrops in rural agricultural catchments: the Chalk, Lincolnshire Limestones; parts of the Shropshire Sandstone in the west of England and Nottinghamshire Sandstones in the East Midlands. They consider that lower nitrate occurrences in the major aquifer groundwater bodies, although potentially ascribed to denitrification, may also be controlled by the increased presence of overlying drift deposits and, or reduced agricultural loading perhaps in urban centres. These processes are not easily distinguishable based on nitrate concentrations and lithology alone, a range of hydrochemical and isotope techniques have been used effectively to constrain denitrification processes (e.g. Feast et al., 1998; Gooddy and Darling, 2009; Lapworth et al., 2008b). Alternative urban sources may, however, still be significant and explain some elevated occurrences; for example, the Birmingham aquifer in the West Midlands, underlying the UK's second city, is classified in the maximum concentration band. The data also indicate lower concentrations across area which are underlain by poorly productive strata.

Stuart et al. (2007) assessed data from the major aquifers in England and calculated predicted concentrations for the $1^{\text {st }}$ January 2000 using a statistical technique to model long-term trends (Table 2). This assessment showed that the median concentrations of four major aquifers, namely the Chalk, PermoTrias, Oolite and the Lower Greensand were higher than the overall average namely 9.8 to $11.7 \mathrm{mg} / \mathrm{L}$. Results from the Lincolnshire Limestone indicated somewhat lower concentrations, which could be due to the positive impact of the introduction of measures aimed at reducing nitrate pollution in this rapidly responding aquifer. Results from the Permian limestone aquifer give a lower average concentration because a large proportion of the sites studied were in the confined aquifer and therefore subject to denitrification. The variation in this aquifer was greater than for the major aquifers.

The highest nitrate concentrations occurred in the areas around the Wash, from the Chalk of south Yorkshire and East Anglia to the Lincolnshire Limestone and the Yorkshire-Nottinghamshire PermoTriassic sandstone. These broadly correspond to the areas of low effective rainfall, with less potential for dilution during recharge, combined with a large percentage of arable land that was identified as at a high risk of leading to nitrate pollution (Foster et al., 1986). Concentrations in the southern Chalk were lower and generally below $11.3 \mathrm{mg} \mathrm{NO}_{3}-\mathrm{N} / \mathrm{L}$. These compared well with the assessments for southern England (e.g. Jones and Smart, 2005; Limbrick, 2003).

More recent work by Howden and Burt (2009) has demonstrated the evidence for hydrogeological controls on trends in nitrate concentrations in the Chalk of south west England.. There were very few datasets from the western side of England and Wales available for assessing long-term trends, other than the work in mid Wales reported by Robins et al. (2000) and Shand et al. (2005). 
For Scotland, Robins (2002) found that nitrate pollution of groundwaters was least in the Highlands and greatest in the Southern Uplands where a significant proportion of samples exceed $11.3 \mathrm{mg}-\mathrm{N} / \mathrm{l}$ (Table 3). The aquifers with the highest occurrence of nitrate were the Devonian aquifers of Fife and parts of Strathmore, the Permian basin aquifers at Dumfries and Ayrshire and parts of the volcanic aquifers in the Lothians. These all reflect intensive cultivation or grassland usage in which annual nitrate leaching losses from fertiliser are likely to exceed $40 \mathrm{~kg} / \mathrm{ha}$. MacDonald et al. (2005) assessed that groundwater across $14 \%$ of Scotland was at risk of exceeding the $11.3 \mathrm{mg} \mathrm{NO}_{3}-\mathrm{N} / \mathrm{L}$ standard.

For Northern Ireland, Robins (1998) found that nitrate concentrations were modest when compared to some parts of the UK. Given the density of grassland dairy farming, these concentrations could be considered surprising but were ascribed to a high effective rainfall, which dilutes leached nutrients and widespread moisture-retaining, heavy gley soils which promote denitrification.

Literature values for $\mathrm{NO}_{3}-\mathrm{N}$ from other UK studies are shown in Table 3. These reflect the importance of the Chalk aquifer to UK water supply and confirm the current trends in concentration.

\subsubsection{Trends}

Stuart et al. (2007) also assessed their data for long-term trends. The model included an assessment of seasonality. The average trend in groundwater nitrate concentrations was estimated to be upwards at an overall rate of about $0.077 \mathrm{mg} \mathrm{NO}-\mathrm{N} / \mathrm{L} / \mathrm{a}$ (Table 2). These compared well with the assessments for southern England (e.g. Jones and Smart, 2005; Limbrick, 2003). In the Chalk and Permo-Triassic sandstone, the average was slightly greater $(0.09 \mathrm{mg} \mathrm{NO}-\mathrm{N} / \mathrm{L} / \mathrm{a})$. The steepest median trend was in the Lincolnshire Limestone aquifer $\left(0.22 \mathrm{NO}_{3}-\right.$ $\mathrm{N} / \mathrm{L} / \mathrm{a})$ and lowest was in the Jurassic Oolitic limestone aquifer $\left(0.01 \mathrm{mg} \mathrm{NO}_{3}-\mathrm{N} / \mathrm{L} / \mathrm{a}\right)$. The data from the Permian limestone aquifer had the greatest range, reflecting the contrast between the confined (reducing) and unconfined (aerobic) aquifers. Overall, there were more sites with increasing trends than with decreasing trends in all of the aquifers.

These results for the Chalk were broadly consistent with the trend of $0.09 \mathrm{mg} \mathrm{NO}_{3}-\mathrm{N} / \mathrm{L} / \mathrm{a}$ reported by the European Environment Agency (1999) and those of Beeson and Cook (2004) who found a linear increase of 0.29, 0.20 and $0.11 \mathrm{mg} \mathrm{NO}-\mathrm{N} / \mathrm{L} / \mathrm{a}$ for three sites in the Chalk of eastern England.

Nitrate concentrations are increasing in some areas of Scotland, although not all. In the Permian basin of Dumfries, a public supply borehole that was commissioned in 1978 had a $\mathrm{NO}_{3}-\mathrm{N}$ concentration of $1.4 \mathrm{mg} / \mathrm{L}$ in 1983, rose steadily to reach $5.9 \mathrm{mg} / \mathrm{L}$ in 1998. This rise reflects a massive increase in abstraction in that area, coupled with continued nitrate loading on grassland in the main recharge area a few kilometres to the north. In the Devonian aquifer of Stratheden, intensive agricultural activity, particularly the cultivation of vegetables, has resulted in a steady increase in nitrate concentration in many boreholes.

Wang et al. (2012) applied a process-based model to predict regional scale nitrate loading at the water table. This showed that travel time in the unsaturated zone can be very important for aquifers with significant topography. These include the Chalk, Millstone Grit, Scottish Old Red Sandstone and the Coal Measures. These long travel times will be important for influencing future trends. 


\subsubsection{Context and implications}

Nitrate pollution of groundwater across Western Europe has been recognised for several decades e.g. (Strebel et al., 1989) and from the late 1990s the impact of mitigation measures has been assessed (Oenema et al., 1998). Baseline data from sand and gravel aquifers in Flanders, Belgium had mean $\mathrm{NO}_{3}-\mathrm{N}$ values of between 0.5 and $1.5 \mathrm{mg} / \mathrm{L}$, similar to Quaternary aquifers in the Uk baseline study, but with a P90 of 27 $\mathrm{mg} / \mathrm{L}$ in Meuse and Rhine river deposits (Coetsiers et al., 2008). Nitrate concentrations resulting from intensive agriculture have continued to rise in other parts of Belgium and the Netherlands (Batlle Aguilar et al., 2007; Mendizabal et al., 2012). In Denmark despite the reversal of overall trends almost $50 \%$ of oxic groundwater has concentrations of nitrate above the $11.3 \mathrm{mg} / \mathrm{L}$ limit. (Hansen et al., 2012) Downwards trends are often difficult to interpret in borehole monitoring data and can require depth profiles (Broers and van der Grift, 2004)

Of the three macronutrients in this study, nitrogen species are the only ones which have European drinking water limits (under the Drinking Water Directive 98/83/EC). Nitrate exceeds this limit in some groundwater, predominantly in agricultural areas. This has implications for drinking water utilities in the cost and reliability of treatment to meet the regulation quality. Elevated nitrate concentrations in groundwater may also impact on surface water where baseflow is significant and on groundwater dependent ecosystems (Rozemeijer and Broers, 2007; Sánchez-Pérez et al., 2003). The roles of nitrate and phosphate are interlinked in the surface water eutrophication process (Smolders et al., 2009).

In the UK groundwater quality and trends are particularly difficult to interpret and manage due to sometimes decades-long unsaturated zone travel times, which delay the arrival of peak concentrations. This can result in a disconnection between current land use (and any mitigation actions) and groundwater quality. This is in addition to issues related to stratification, for example the screening out shallow high nitrate water allowed abstraction of older low nitrate water and maintenance of drinking water quality (Osenbrück et al., 2006). Stuart et al. (2011) concluded that the implications for N leaching to groundwater as a result of climate changes are not yet well enough understood to be able to make useful predictions. Likely nitrate leaching ranging from limited increases to a possible doubling of aquifer concentrations by 2100 are predicted if changes to agricultural practice are not made. The predicted impact of climate change on nitrate concentrations appears to be less than the predicted changes to concentrations resulting from measures to reduce agricultural nitrate leaching.

Research priorities for understanding $\mathrm{N}$ species in groundwater are long established, but have developed from evaluating the movement of $\mathrm{N}$ from diffuse and point sources to the study of the impact of $\mathrm{N}$ in baseflow to sensitive receptors and the impacts of climate change.

\section{Phosphorus}

\subsection{Sources of phosphorus in groundwater}

The main sources of anthropogenic P are considered to be NPK fertilisers and animal and human wastes (Holman et al., 2008b). Holman et al. (2008a) set out the main sources in more detail as: 
- Agricultural soils - arable and grassland

- Septic tanks and leaking sewers

- Water treatment works

- Leaking water pipes - orthophosphate dosing for plumbosolvency

- Earth-lined slurry lagoons and manure heaps

Additionally, both wet and dry deposition provides P to the surface. Aerial inputs are estimated at $0.22 \mathrm{~kg} / \mathrm{ha} / \mathrm{yr}$ in SW England and 0.0.12 kg/ha/yr in upland NE Scotland (Haygarth et al., 1998). Unlined legacy landfill sites may also be a potential point source of anthropogenic $P$.

The dominant natural source of $\mathrm{P}$ in groundwater is apatite present in the aquifer matrix, especially fluorapatite and exchangeable $\mathrm{P}$ on iron oxides (either desorbed) or dissolved during reductive dissolution (Shand et al., 2007). There is relatively limited information on sources in aquifer materials. Acid extractable $\mathrm{P}$ and \% organic carbon data from Milne and Kinniburgh (2006) are presented as box-plots in Figure 4. Of the major UK aquifers (i.e. Chalk, Sandstone and Limestone) Chalk (shown as the blue boxplot) has the highest median extractable P (Figure 4a) followed by Sandstone and Limestone, the Chalk has the lowest $\%$ OC (Figure 4b).

\section{Chalk}

In the White Chalk, the bulk of the rock is composed of a low-magnesian calcite with a small percentage of clay minerals, quartz and minor amounts of apatite. In a few localised areas, however, this latter component comes to make up a large proportion of the rock (Kennedy and Garrison, 1975). Pacey (1985) studied three areas of phosphatic chalk and found that deposits of pelletal phosphates in the Chalk are made up of various phosphatised bioclasts, mainly the faecal pellets of detrital feeding organisms such as worms and crustaceans.

\section{Permo-Triassic sandstone}

The sandstone cements include a wide range of minerals including calcite, dolomite, gypsum, anhydrite, halite, iron oxide and clays. Grain coatings within the Sherwood Sandstone Group include iron oxides and smectite. Heathwaite and Dils (2000) refer to phosphatic nodules embedded in marine bands.

\section{Greensand}

Greensand, particularly the Lower Greensand and Lower Gault, including the Hythe and Bargate formations contain beds of phosphatic nodules (Owen, 1960).

\subsection{Phosphorus speciation in groundwater}

The species of $\mathrm{P}$ in natural waters are conventionally divided into three component groups: soluble reactive $\mathrm{P}$ (predominantly o- $\mathrm{PO}_{4}$ ) (SRP), soluble unreactive (colloidal, polymeric or organic P) (SUP), and particulate P (PP). The sum of SRP and SUP is defined as total dissolved P (TDP) and the sum of all components is termed total P (TP). Dissolved and particulate P are differentiated by whether or not they pass through a $0.45 \mu \mathrm{m}$ filter; $\mathrm{P}$ is reactive when it is available to react with molybdate/ascorbic acid reagent to form "molybdenum blue". 
$\mathrm{P}$ can be determined by a variety of methods which will determine the species being measured: ICP-OES on the filtered samples reported as TDP, ion chromatography gives o-PO4 and SRP is predominantly but not entirely o- $\mathrm{PO}_{4}$. Orthophosphate is the $\mathrm{P}$ form that is directly taken up by algae, and the concentration of this fraction constitutes an index of the amount of $\mathrm{P}$ immediately available for algal growth.

\subsection{Phosphorus fate and transport in groundwater}

\subsubsection{Sorption to the aquifer matrix}

Holman et al. (2008a) reviewed P fate and transport in groundwater for SNIFFER. They state that nder alkaline conditions $\mathrm{P}$ is preferentially fixed by calcium and magnesium compounds, hence its mobility is generally limited. This is the reason why $\mathrm{P}$ has not been considered as significant in groundwater (e.g. in Klepper et al., 1995). However, groundwater $\mathrm{pH}$ values of $<7$ and undersaturation with respect to calcite are both widely observed in UK groundwaters, facilitating $\mathrm{P}$ transport in the subsurface (e.g. Edmunds and Kinniburgh, 1986). A large proportion of $P$ in water occurs in particulate form and it is likely that TDP contains a colloidal component.

Groundwater concentrations tend to be lower than those for surface water. This has been ascribed to:

1. Active $\mathrm{CaCO}_{3}$ precipitation in groundwater - Jarvie et al. (2005) found that calcite saturation (SI) values for the groundwater of the predominantly Chalk Hampshire Avon catchment groundwater average about zero with a range of 5 times under or over saturated. The SI values for groundwater indicated that either $\mathrm{CaCO}_{3}$ precipitation is actively occurring within the groundwater or calcite is dissolving (when SIcalcite $<$ ). $\mathrm{CaCO}_{3}$ precipitation in groundwater is probably able to occur as a result of the greater availability of nucleation sites within the aquifer (Neal et al., 2002). Neal et al. (2002) found Chalk groundwater averaged $14 \mu \mathrm{g} / \mathrm{L}$ SRP in the Kennett Valley showing calcite solubility controls were operative.

2. Sorption to (amorphous) iron hydroxides - Edmunds et al. (1982) ascribed P in the East Midlands Triassic sandstone aquifer to input in rainfall. As water moves down the redox gradient low concentrations are due to removal of phosphate in solution by adsorption to amorphous $\mathrm{FeOH}$.

3. Long residence times in aquifers with matrix flow - Jarvie et al. (2005) found higher concentrations of TRP ( $>100 \mu \mathrm{g} / \mathrm{L})$ in samples from the upper River Nadder catchment in the Upper Greensand where there is fissure flow. The higher TRP concentrations in these Upper Greensand boreholes may reflect natural P present in the aquifer matrix or groundwater transport that is predominantly fissure flow. For this situation, uptake by the carbonate matrix is likely to be limited by lower water residence times and flow which bypasses the aquifer matrix.

\subsubsection{Groundwater receptors}

Holman et al. (2010) set out the factors which would allow P to be transported from the aquifer to receptors as:

- Sorption potential of the aquifer matrix related to combined iron hydroxides and $\mathrm{CaCO}_{3}$ content.

- Retardation by slow diffusion into micropores. 
- Degree of contact as dictated by flow type, bypass flow etc.

- Time available for sorption - residence time, length of flowpath

- $\quad$ Role of $\mathrm{HZ}$ - steep gradients in redox potential

Groundwater concentrations are generally low but continuous baseflow may nevertheless contribute a significant amount to the overall catchment loading. Bowes et al. (2005) were able to achieve a catchment $P$ mass-balance taking account of $P$ in groundwater baseflow contribution to the River Frome. Heathwaite and Dils (2000) measured the shallow groundwater contribution to stream flow as between 210 and 500 $\mu \mathrm{g} / \mathrm{L}$ depending on depth, but which contributes throughout the year in the glacial tills of the Pistern catchment.

Edwards and Withers (2007) discuss P source apportionment and classified inputs as diffuse near surface (episodic) and groundwater flows (continuous - i.e. essentially independent of precipitation events). P in groundwater tends to be at low concentrations but is mainly in the dissolved phase and therefore more bioavailable.

Neal et al. (2003) noted that SRP concentrations in stream water and ground water are lower than in atmospheric inputs and surface soil waters and show marked spatial variability. This variability is linked to catchment features. For streams draining podzolic soils, most of the SRP is retained by the catchment. For this situation, stream and groundwaters have average concentrations of approximately $0.05 \mu \mathrm{M} / \mathrm{L}$ (1.5 $\mu \mathrm{g} / \mathrm{L})$, with a range of $0-1.47 \mu \mathrm{M} / \mathrm{L}(0-45.6 \mu \mathrm{g} / \mathrm{L})$. For forested catchments with gley soils, stream water SRP concentrations are more variable with, in one case, much higher concentrations than for the podzol counterparts (range in average 0.05-0.46 $\mu \mathrm{M} / \mathrm{L})(1.5-14.2 \mu \mathrm{g} / \mathrm{L}$ ). For streams draining gley soils there is an enrichment with peak concentrations of $4 \mu \mathrm{M} / \mathrm{L}(124 \mu \mathrm{g} / \mathrm{L})$ recorded.

High average Chalk TDP (45-56 $\mu \mathrm{g} / \mathrm{L})$, SRP $(36 \mu \mathrm{g} / \mathrm{L})$ and TP $(45-64 \mu \mathrm{g} / \mathrm{L})$ values were found for spring samples discharging from the base of the Chalk in the Beult catchment, Kent (Lapworth et al., 2013), either suggesting disequilibrium with calcite or perhaps additional P sources from mains water leakage (Gooddy et al., 2015). Sorensen et al. (2013) compared bulk borehole and aquifer chemistry and ecology using packer sampling to show that the borehole environment was depleted in SRP and enriched in PP, DHP, (as well as $\mathrm{NO}_{3}$ and $\mathrm{DOC}$ ) with respect to the aquifer water, implying that there was localised biological cycling of macronutrients within the borehole environment.

\subsection{P concentrations in groundwater: results and discussion}

\subsubsection{Baseline study}

Baseline data for P were determined on filtered samples, and are therefore usually reported as TDP. A summary of these data for each aquifer is shown in Table 4. Looking at the dataset as a whole 5 of the 10 aquifers with the lowest median TDP are limestones, the others being the sandstones of the south west (The Otter Sandstone of Devon and Somerset and the Devonian sandstones and the Millstone Grit and Corallian of Northern England) (Figure 5). Five of the 10 aquifers with the highest median TDP are sandstones, mainly the Permo-Triassic sandstones of the Midlands and northern England, and the Bridport Sand, the others being Chalk with the highest in the Colne-Lee. 


\subsubsection{Literature data}

Holman et al. (2008a) compare BGS baseline data with samples collected by the Environment Agency (EA) as part of the national monitoring programme and also include the other members of the British Isles. Data were grouped and averaged at Groundwater Body level. BGS data appear to be significantly higher in some cases. BGS samples are filtered on-site whilst EA samples are not. Holman et al. (2008a) suggest that this analysis does not adequately capture the distribution of $\mathrm{P}$ concentrations, but also state that at least some of these high concentrations were measured in confined parts of the aquifer where there is limited circulation.

In England and Wales P concentrations were stated to be relatively high compared to the rest of the UK. A number of groundwater bodies have median concentrations $>60 \mu \mathrm{g} / \mathrm{L}$ with a notable cluster of high concentrations in the English northwest. Where there is data available $15 \%$ of aquifers exceeded $30 \mu \mathrm{g} / \mathrm{L}$ and $5 \%$ exceeded $60 \mu \mathrm{g} / \mathrm{L}$ by area. In Scotland relatively few data are available with $9 \%$ of aquifers exceeding $30 \mu \mathrm{g} / \mathrm{L}$ and $1 \%$ exceeding $60 \mu \mathrm{g} / \mathrm{L}$ by area. These were mainly in the east. For Northern Ireland, 2 aquifers exceeded $30 \mu \mathrm{g} / \mathrm{L}$ but had only 1 sample each.

In this study, Holman et al. (2008b) used a number of simple land use classes to look at P controls. This showed that:

- The observed concentrations are higher in England and Wales for each of the land use classes relative to Scotland and Northern Ireland

- Concentrations under semi-natural scrub or woodland area are generally lower than urban and arable

- The concentrations in arable area are very variable

- There are few data in Scotland except urban and grassland

\subsubsection{Context and implications}

Historically phosphorus in groundwater has not been a concern. Compared to other major ions and nutrients phosphate concentrations are low $(<1 \mathrm{mg} / \mathrm{L})$ and there is no drinking water limit. Coetsiers et al. (2008) report baseline concentrations of between 0 and $0.5 \mathrm{mg} / \mathrm{L}$ as $\mathrm{PO}_{4}$ for sand and gravel aquifers in Belgium, rather higher than to concentrations observed in the rural Quaternary aquifers summarised in this study.

With increasing of the impact of phosphate fertilizers and sewage treatment effluent on the aqueous environment, we can expect to see a reduction in P discharge to the environment. It is not yet clear what proportion of $\mathrm{P}$ in groundwater is of anthropogenic origin. There is as yet little data on the reduction in groundwater P from agricultural measures as these tend to focus on surface water impacts (Oenema et al., 2005). The source of $P$ to the aqueous environment represented by addition of phosphate to drinking water to control plumbosolvency has become increasing recognised (Ascott et al., 2016). Up to 1200 tonnes of $P$ may be lost through mains leakage every year and will become more significant as phosphate stripping in sewage treatment works continues to improve. P inputs to the environment from leakage are concentrated 
in urban centres and in many cases these are close to surface water bodies including estuaries(Ascott et al., 2016).

The impact of groundwater as baseflow to surface water systems has become an important topic, and the impact on coastal waters from estuaries and from submarine discharges is likely to become so and may be a significant input to the shallow coastal system in some locations (e.g. Lecher et al., 2015; Rodellas et al., 2014), although very little work has been done on this topic to date in the UK. For marine receptors the ecological sensitivity is likely to be well below $1 \mathrm{mg} / \mathrm{L}$. Analysis for P species in groundwater has become more sophisticated, analogous to longer-established surface water practice, and a useful body of UK data for soluble reactive $\mathrm{P}$ in groundwater, for example, is developing.

Rozemeijer and Broers (2007) showed that non-conservative contaminants, such as total P, migrate only slowly downwards through the aquifer and thus show large contributions to surface water during rapid flow events. With the increasing frequency of extreme climatic events in the UK, it would be reasonable to assume that higher loadings of mobile $\mathrm{P}$ will be discharged to groundwater receptors in the future.

Research priorities for groundwater $\mathrm{P}$ will therefore include establishing the distribution of species making up the total $\mathrm{P}$ loading to enable modelling of $\mathrm{P}$ in the aqueous environment and determining the loading in baseflow to sensitive surface, estuarine and coastal waters.

\section{Organic carbon}

\subsection{Sources of organic carbon in groundwater}

Most DOC is derived from soils and can play an important part in redox processes and in solute transport. Aquifers can contain high organic carbon and contribute significantly to the DOC of groundwater. In addition pollution may also enhance groundwater concentrations, e.g. beneath slurry pits and around landfill sites.

The organic content of British aquifers was reviewed by Stuart (1991). This showed there were two main groups of analyses: the first designed to isolate fractions of organic material undamaged and the second to achieve a controlled degradation to characterise chemical functions or to obtain hydrolysis products, such as amino acids and carbohydrates. West and Chilton (1997) discuss the DOC content of the principal British aquifers in terms of support for microbiological populations and provide average data for the Chalk $(0.2 \%)$, Jurassic limestone $(0.05 \%)$ and Permo-Triassic sandstone (2\%).

\section{Chalk}

The Chalk has been the most closely studied of the major British aquifers. Whitelaw and Edwards (1980) found $530 \mathrm{mg} / \mathrm{kg}$ total carbohydrates, predominantly mannose and glucose, in the Chalk unsaturated zone thought to result from infiltration of soil water and bacterial release of soluble polysaccharides. This was deemed sufficient to have a profound effect on groundwater composition, for example in terms of denitrification potential. 
Pacey (1989) showed Chalk contains organic matter in the form of humic and fulvic acids, humin and solvent soluble carbon (here called bitumen). Levels of total humic matter range from $\sim 0.01 \%$ in the white chalks to $0.1 \%$ in the clayey and phosphatic chalk facies; reaching $1 \%$ in a sample of the Black Band near the base of the White Chalk Group in northeastern England. Less than $30 \%$ of the total humic matter in the samples was amenable to direct extraction, the bulk (and all the bitumen) being obtainable only after dissolution of carbonates or of all mineral phases (as humin). Bitumins were 0.01 to $0.15 \%$ and comprised mainly asphaltenes. This points to a diffuse distribution of organic matter in the chalks, between the calcite and associated with clays. The slow leaching of humic acids from the chalk matrix gives rise to a characteristic fluorescence signal in groundwater.

\section{Lincolnshire Limestone}

Gehman Jr (1962) determined total organic matter and bitumen in a wide range of limestones. TOC ranged from 0.01 to $7 \%$ with an average of $0.2 \%$. Bitumens ranged from 3 to $6000 \mu \mathrm{g} / \mathrm{L}$ with a mean of $98 \mu \mathrm{g} / \mathrm{L}$. Oolitic limestones appeared to have retained an appreciable quantity of soluble polar material due to their formation under reducing conditions. Organic material is often not evenly distributed in limestone but occurs in fissures and nodules associated with mineralisation (Smith et al., 1990).

For the Lincolnshire Limestone, Lawrence and Foster (1986) found that the rock matrix contained significant quantities of organic carbon with both kerogen and bitumen fractions. Lower values of organic carbon, mainly kerogen, were found in the oxidized buff limestone (0.01-0.07\% by weight) compared with the non-oxidized grey limestone ( $0.1 \%$ by weight). Values as low as were found in the buff limestone. Analysis of mobile fissure water gave values of DOC of less than $2 \mathrm{mg} / \mathrm{L}$. Hiscock et al. (2011) estimated the carbon utilisation rate using reactive transport modelling. The predicted rates were $0.13 \mathrm{mg} / \mathrm{L} /$ day close to the outcrop and 0.07 $\mathrm{mg} / \mathrm{L} /$ day $6.5 \mathrm{~m}$ from outcrop. They calculated that if all the organic carbon were biodegradable then the carbon in the rock matrix would be utilised in about 200 years thus suggesting a natural limit on denitrification.

\section{Permo-Triassic sandstone}

Analysis of Triassic sandstone samples from Yorkshire showed low levels of bitumens, generally less than $0.05 \%$ thought to comprise mostly asphaltenes with no detectable kerogen (BGS unpublished data). TOC was in the range $0.02-0.07 \%$.

\subsection{Organic carbon speciation in groundwater}

Organic matter in surface and groundwater is a diverse mixture of organic compounds ranging from macromolecules to low molecular weight compounds such as simple organic acids and short-chained hydrocarbons (Aiken, 2002). Historically, organic matter in natural waters has been arbitrarily divided into dissolved (DOC) and particulate organic carbon (POC), based on filtration through a $0.45 \mu \mathrm{m}$ filter; a silver filter can also serve to preserve the sample. No natural cut-off exists between these two fractions and the distinction is arbitrary. Overlapping the dissolved and particulate fractions is the colloidal fraction, which consists of suspended solids that are operationally considered solutes. Colloidal organic matter in natural waters is composed of living and senescent organisms, cellular exudates, and partially-to-extensively 
degraded detrital material, all of which may be associated with mineral phases. Generally, DOC is in greater abundance than POC, accounting for approximately $90 \%$ of the total organic carbon of most waters.

The nature of most DOC in groundwater is poorly documented and its ability to drive redox processes and solute transport is determined by the reactivity of the components. Dilling and Kaiser (2002) separated DOC into two categories: low molecular-weight compounds (such as acetate) and high molecular-weight compounds. The former were assumed to be more biologically reactive (Kaiser et al., 2002).

Work by several authors has employed fluorescence spectroscopy to show that terrestrial derived humic substances (e.g. humic and fulvic acids) dominate bulk groundwater DOC composition, and correlate with DOC (Baker and Curry, 2004; Baker and Lamont-BIack, 2001; Lapworth et al., 2009; Lapworth et al., 2008a; Lapworth et al., 2011; Rhymes et al., 2015). However, more labile protein-like dissolved organic matter (DOM) may also be present in detectable concentrations, particularly where rapid flow pathways in the subsurface are present, from surface sources such as landfills, rivers, urban waste water and agricultural inputs (e.g. Baker and Curry, 2004; Lapworth et al., 2009; Lapworth et al., 2008a; Rhymes et al., 2015; Tye and Lapworth, 2016).

Using groundwater fluorescence Lapworth et al. (2008a) showed that sites in the Sherwood Sandstone of Yorkshire had a predominantly terrestrial source of DOM reflecting a relatively shallow source and others near the base suggesting a microbial source i.e. degradation of sources within the aquifer. In the Penrith Sandstone fluorescence combined with CFCs suggested a rapid flow route to $60 \mathrm{~m}$ depth possible fracture flow and increasing recalcitrant fulvic acid content with depth in the rest of the profile. A recent study by Tye and Lapworth (2016) showed higher humification indices in groundwater compared to soils suggesting continued processing of DOM within the aquifer.

\subsection{Organic carbon fate and transport in aquifers}

Organic carbon is consumed in aquifers by supporting microbiological processes. Many different types of bacteria are viable within the typical pH/Eh ranges of British aquifers 6-8.5 (West and Chilton, 1997). The surface area of the aquifer matrix is very large compared to the water volume so opportunities for carbon going into solution. However organic carbon availability generally decreases rapidly with depth. Pabich et al. (2001) observed at the Cape Cod site, USA that there was considerable attenuation of DOC in the unsaturated zone and that $99 \%$ was attenuated by a depth of $19 \mathrm{~m}$ below the surface. There was a strong inverse relationship with nitrate. DOC was very spatially variable but stable over time at any one site.

Most discussion of organic carbon consumption in groundwater relates to denitrification. Denitrifiers are mostly facultative anaerobic heterotrophs and hence obtain both their energy and carbon from the oxidation of organic compounds. Lack of organic carbon is usually identified as the major factor limiting denitrification rates in aquifers (Pabich et al., 2001; Starr and Gillham, 1993). Subsurface environments with high concentrations of labile organic matter and reducing conditions are likely to be particularly significant zones for denitrification. These include riparian zones (Burt et al., 1999; Puckett, 2004), hyporheic zones (Smith and Lerner, 2008), and aquifers affected by infiltration of DOC-rich surface water (Roberts and McArthur, 1998). 
Fiebig and Lock (1991) measured the loss of organic carbon from groundwater with $20-25 \mathrm{mg} / \mathrm{L} \mathrm{DOC}$ as it discharged through streambed material for two upland streams in Wales. Carbon was immobilised at a rate dependent on the incoming concentration.

\subsection{Organic carbon in groundwater: results and discussion}

\subsubsection{Baseline studies}

Dissolved carbon in the BGS study represents the sum of organic material after filtering through a $0.45 \mu \mathrm{m}$ Ag-membrane silver filter.

Baseline concentrations for the aquifers of the UK are shown in Table 5. There is little obvious overall lithological pattern with sandstones and chalk being represented in the top 10 median concentrations and sandstones, chalk, and igneous in the bottom 10 (Figure 6).

\subsubsection{Literature data}

Rivett et al. (2007) summarise DOC data collected by the Environment Agency (Table 6). The data are typically skewed to the lower end of the distribution with means between 0.71 and $1.49 \mathrm{mg} / \mathrm{L}$. DOC rarely exceeds $5 \mathrm{mg} / \mathrm{L}$. Concentrations are highest in the Quaternary and the Carboniferous aquifers and lowest in the Chalk and Jurassic limestones.

Dissolved organic C (DOC) concentrations in UK groundwaters have a large range (0.18-18.6 mg C/L, n = 113) with mean concentration of 3.09 (Gooddy and Hinsby, 2008). This is said to be a reflection of both the different sources of DOC and different aquifer properties. For example, TOC (total organic C) concentrations in two Permo-Triassic Sandstone aquifers have a broader range and generally higher TOC concentrations than Chalk aquifers in the UK and this could be due to the larger pore throat sizes found in sandstone systems.

For East Midlands groundwater Edmunds et al. (1982) found most samples had DOC concentrations below their detection limit $(0.1 \mathrm{mg} / \mathrm{L}$ ). DOC in groundwater in the Chalk of Kent ranged from 0.8 to 1.52 except in sites where there was evidence of STWs or contamination from fuels (Lapworth and Gooddy, 2006).

For sites in upland mid Wales, Lapworth et al. (2008b) found the range of DOC in groundwater ranging from $0.4 \mathrm{mg} / \mathrm{L}$ to $10.6 \mathrm{mg} / \mathrm{L}$ with a median of $2.1 \mathrm{mg} / \mathrm{L}$. All samples were below $4.3 \mathrm{mg} / \mathrm{L}$ except one. DOC was variable and showed highest concentrations in the winter and spring possibly due to dilution by increased recharge. Neal et al. (2005) measured groundwater DOC at Plynlimon. The range was 0.42 to 1.49 $\mathrm{mg} / \mathrm{L}$. They found lower concentrations in baseflow and higher in stormflow.

\subsubsection{Context and implications}

Gooddy and Hinsby (2008) present data on TOC and DOC concentrations in groundwater from eight European countries, TOC was found at a median concentration of $2.7 \mathrm{mg} \mathrm{C} / \mathrm{L}$ with a range from $0.1-59.4$ $\mathrm{mg} \mathrm{C} / \mathrm{L}$ and DOC had a median concentration of $2.2 \mathrm{mg} \mathrm{C} / \mathrm{L}$ with a range from $0.2-58.9 \mathrm{mg} \mathrm{C} / \mathrm{L}$, demonstrating that very high natural organic carbon values can occasionally be found locally in some 
pristine aquifers such as the Ribe Formation in Denmark. They emphasise the importance of collecting TOC or DOC data for all groundwater samples. The DOC data for the UK fall well within the European range.

There remains little data on the composition of soluble organic carbon in groundwater and this remains an area for research. There are no drinking water limits for unspeciated OC but organic content does have implications for drinking water disinfection using chlorine or related reagents. The formation of THMs and haloacetic acids during water disinfection has been long recognised and widely documented (Adin et al., 1991; Liang and Singer, 2003; Singer, 1999). This will continue to pose challenges to water supply utilities (Ritson et al., 2014).

Groundwater will contribute dissolved organic carbon, albeit at typically low concentrations $(<5 \mathrm{mg} / \mathrm{L})$ to surface water and groundwater-fed wetlands via baseflow. This is likely to contain a higher proportion of refractory matter than surface water due to its long residence time and the biological processing of DOM within the aquifer. The impact of this carbon input to surface water, and to coastal waters, is as yet largely unknown for the UK. However, with increasing frequency of extreme climatic events, changes in catchment acidification and temperature in the UK (e.g. Clark et al., 2010; Evans et al., 2012), it may be reasonable to assume that higher loadings of DOM may be discharged to groundwater and surfaces water receptors via shallow groundwater flowpaths in the future, with possible implications for nutrient cycling in groundwater and baseflow dependant ecosystems.

\section{Conclusions}

- Nitrogen species are relatively well-quantified in groundwater and have a wide concentration range, with $\mathrm{NO}_{3}-\mathrm{N}$ concentrations ranging from below the detection limit to over $11.3 \mathrm{mg} / \mathrm{L}$. On the local scale the concentrations are very heterogeneous due to differences in landuse, flow regime and residence time, and redox potential.

- Nitrate concentrations in groundwater have increased in groundwater since the 1950s reaching peak inputs during the 1980s and early 1990s. Since then changes in agricultural practice under the Nitrate Directive are leading to a reduction in concentration which can now be observed at some sites in the more rapidly responding aquifers. For the Chalk aquifer, the thick unsaturated zone means that these improvements may not be seen for some decades in places, with implications for continued impacts on receptors that receive baseflow inputs and sub marine groundwater discharges.

- Phosphorus is less well-characterised in groundwater than nitrogen. $\mathrm{P}$ is present in the aquifer matrix and this may be a significant source. There is a lack of historical interest in $\mathrm{P}$ and $\mathrm{P}$ speciation in groundwater. The highest concentrations, in groundwater, with median values typically $>50 \mu \mathrm{g} / \mathrm{L}$, are found in sandstones, such as the Permo-Triassic sandstones of the Midlands and northern England, in some areas of the Chalk and in eastern Scotland. There is little information on P speciation or trends in groundwater and further work is needed in this area.

- Most DOC is derived from soils and can play an important part in redox processes. The aquifer matrix can contain high OC and contribute significantly to the DOC of groundwater. DOC median 
values in groundwater range between 0.7 and $1.5 \mathrm{mg} / \mathrm{L}$ and rarely exceed $5 \mathrm{mg} / \mathrm{L}$. There is little information on speciation, however fluorescence techniques are now being used to assess DOM.

- $\quad \mathrm{N}$ and $\mathrm{P}$ species and DOC in groundwater may not in themselves be of concern but will impact on surface water baseflow, groundwater-dependent wetlands and submarine freshwater discharges with consequences for coastal waters. Groundwater plays an important role in controlling the $\mathrm{N}$ and $\mathrm{P}$ nutrient dynamics (i.e. ratio of $\mathrm{N}: \mathrm{P}$ ) within nutrient sensitive ecosystems. The residence time of groundwater systems needs to be taken into account for example when assessing the impact of changes in land use policy within agricultural sector. With the increasing frequency of extreme climatic events in the UK, it would be reasonable to assume that higher loadings of macronutrients will be discharged to groundwater receptors in the future.

- Elevated concentrations of $\mathrm{N}$ species, and in particular nitrate, pose a threat to drinking water quality and have implications for the cost of water treatment. DOC does not have a health impact directly but results in the formation of undesirable disinfection by-products. Phosphate is currently removed from wastewater by an improving programme of $\mathrm{P}$ stripping but is added to potable water to control plumbosolvency and is transported into the environment via mains leakage.

\section{Acknowledgements}

This work was funded by the Long-Term-Large-Scale Project (LTLS) as a part of the NERC Macronutrients Cycles Programme, Grant no. NE/J011533/1. The authors are grateful to Dr Pauline Smedley for providing access to the BGS Baseline dataset and for reviewing this article. The authors publish with permission of the Executive Director, British Geological Survey (NERC).

\section{References}

Abesser C, Shand P, Ingram J.Baseline Series Report 18: The Millstone Grit of Northern England. British Geological Survey Commissioned Report CR/05/015N \& Environment Agency Report NC/99/74/18 2005a.

Abesser C, Shand P, Ingram J.Baseline Series Report 22: The Carboniferous Limestone of Northern England. British Geological Survey Commissioned Report CR/05/076N \& Environment Agency Report NC/99/74/22 2005b.

Abesser C, Smedley PL.Baseline groundwater chemistry: the Carboniferous Limestone aquifer of the Derbyshire Dome. British Geological Survey Open Report OR/08/028 2008.

Adin A, Katzhendler J, Alkaslassy D, Rav-Acha C. Trihalomethane formation in chlorinated drinking water: a kinetic model. Water Research 1991; 25: 797-805.

Aiken GR. Organic matter in water. In: Aiken GR, Kuniansky EL, editors. U.S. Geological Survey Artificial Recharge Workshop Proceedings, April 2-4, 2002, Sacramento, California. U.S. Geological Survey Open-File Report 02-89 2002, pp. 21-23.

Allen DJ, Darling WG, Gooddy DC, Lapworth DJ, Newell AJ, Williams AT, et al. Interaction between groundwater, the hyporheic zone and a Chalk stream: a case study from the River Lambourn, UK. Hydrogeology Journal 2010; 18: 1125-1141.

Ander L, Shand P, Lawrence AR, Griffiths KJ, Hart P, Pawley J.Baseline Series Report 13: The Great Ouse Chalk aquifer, East Anglia. British Geological Survey Commissioned Report CR/04/236N \& Environment Agency Report NC/99/74/13 2004.

Ander L, Shand P, Wood S.Baseline Series Report 21: The Chalk and Crag of North Norfolk and the Waveney Catchment. British Geological Survey Commissioned Report CR/05/043N \& Environment Agency Report NC/99/74/21 2006. 
Ascott M, Gooddy D, Lapworth D, Stuart M. Estimating the leakage contribution of phosphate dosed drinking water to environmental phosphorus pollution at the national-scale. Science of the Total Environment 2016.

Baker A, Curry M. Fluorescence of leachates from three contrasting landfills. Water Research 2004; 38: 2605-2613.

Baker A, Lamont-Black J. Fluorescence of dissolved organic matter as a natural tracer of ground water. Groundwater 2001; 39: 745-750.

Batlle Aguilar J, Orban P, Dassargues A, Brouyère S. Identification of groundwater quality trends in a chalk aquifer threatened by intensive agriculture in Belgium. Hydrogeology Journal 2007; 15: 16151627.

Bearcock JM, Smedley PL.Baseline groundwater chemistry: the Magnesian Limestone of County Durham and north Yorkshire. British Geological Survey Open Report OR/09/030 2009.

Bearcock JM, Smedley PL.Baseline groundwater chemistry: the Palaeogene of the Thames Basin. British Geological Survey Open Report OR/10/057 2010.

Bearcock JM, Smedley PL.Baseline groundwater chemistry: the Sherwood Sandstone of Devon and Somerset. British Geological Survey Open Report OR/11/060 2012.

Bearcock JM, Smedley PL, Milne CJ.Baseline groundwater chemistry: the Corallian of the Vale of Pickering, Yorkshire. British Geological Survey Open Report OR/15/048. 2015.

Beauchamp EG, Trevors JT, Paul JW. Carbon sources for bacterial denitrification. Advances in Soil Science 1989; 10: 113-142.

Beeson S, Cook M. Nitrate in groundwater: a water company perspective. Quarterly Journal of Engineering Geology and Hydrogeology 2004; 37: 261-270.

Bellamy PH, Loveland PJ, Bradley RI, Lark RM, Kirk GJ. Carbon losses from all soils across England and Wales 1978-2003. Nature 2005; 437: 245-248.

Bennett EM, Carpenter SR, Caraco NF. Human impact on erodable phosphorus and eutrophication: a global perspective increasing accumulation of phosphorus in soil threatens rivers, lakes, and coastal oceans with eutrophication. BioScience 2001; 51: 227-234.

Bishop PK, Lloyd JW. Chemical and isotopic evidence for hydrogeochemical processes occurring in the Lincolnshire Limestone. Journal of Hydrology 1990; 121: 293-320.

Bowes MJ, Smith JT, Neal C. The value of high-resolution nutrient monitoring: a case study of the River Frome, Dorset, UK. Journal of Hydrology 2009; 378: 82-96.

Brady NC, Weil RR. The Nature and Properties of Soils. Englewood Cliffs, NJ: Prentice-Hall, 2002.

Broers HP, van der Grift B. Regional monitoring of temporal changes in groundwater quality. Journal of Hydrology 2004; 296: 192-220.

Burt T, Matchett L, Goulding K, Webster C, Haycock N. Denitrification in riparian buffer zones: the role of floodplain hydrology. Hydrological Processes 1999; 13: 1451-1463.

Buss SR, Herbert AW, Morgan P, Thornton SF, Smith JWN. A review of ammonium attenuation in soil and groundwater. Quarterly Journal of Engineering Geology and Hydrogeology 2004; 37: 347-359.

Carey MA, Lloyd JW. Modelling non-point sources of nitrate pollution of groundwater in the Great Ouse Chalk, U.K. Journal of Hydrology 1985; 78: 83-106.

Chilton PJ, Stuart ME, Wagstaff SJ, Coleby LM, Benett J, Jones HK.Identification and quantification of groundwater nitrate pollution from non-agricultural sources. Environment Agency R\&D Technical Report P32. 1996.

Clark JM, Bottrell SH, Evans CD, Monteith DT, Bartlett R, Rose R, et al. The importance of the relationship between scale and process in understanding long-term DOC dynamics. Science of the Total Environment 2010; 408: 2768-75.

Cobbing J, Moreau M, Shand P, Lancaster A.Baseline Series Report 14: The Corallian of Oxfordshire and Wiltshire. British Geological Survey Commissioned Report CR/04/262N \& Environment Agency Report NC/99/74/14 2004.

Coetsiers M, Blaser P, Martens K, Walraevens K. Natural background levels and threshold values for groundwater in fluvial Pleistocene and Tertiary marine aquifers in Flanders, Belgium. Environmental Geology 2008; 57: 1155-1168.

Dilling J, Kaiser K. Estimation of the hydrophobic fraction of dissolved organic matter in water samples using UV photometry. Water Research 2002; 36: 5037-5044.

Edmunds WM, Bath AH, Miles DL. Hydrochemical evolution of the East Midlands Triassic sandstone aquifer, England. Geochimica et Cosmochimica Acta 1982; 46: 2069-2081.

Edmunds WM, Cook JM, Darling WG, Kinniburgh DG, Miles DL, Bath AH, et al. Baseline geochemical conditions in the Chalk aquifer, Berkshire, U.K.: a basis for groundwater quality management. Applied Geochemistry 1987; 2: 251-274. 
Edmunds WM, Doherty P, Griffiths KJ, Shand P, Peach DW.Baseline Series Report 4: The Chalk of Dorset. British Geological Survey Commissioned Report CR/02/268N \& Environment Agency Report NC/99/74/4 2002.

Edmunds WM, Kinniburgh DG. The susceptibility of UK groundwaters to acidic deposition. Journal of the Geological Society 1986; 143: 707-720.

European Environment Agency.Groundwater quality and quantity in Europe. Environmental Assessment Report 3.1999.

Evans CD, Jones TG, Burden A, Ostle N, Zielinski P, Cooper MDA, et al. Acidity controls on dissolved organic carbon mobility in organic soils. Global Change Biology 2012; 18: 3317-3331.

Feast NA, Hiscock KM, Dennis PF, Andrews JN. Nitrogen isotope hydrochemistry and denitrification within the Chalk aquifer system of north Norfolk, UK. Journal of Hydrology 1998; 211: 233-252.

Fiebig DM, Lock MA. Immobilization of dissolved organic matter from groundwater discharging through the stream bed. Freshwater Biology 1991; 26: 45-55.

Foster SSD, Bridge LR, Geake A, Lawrence AR, Parker JM.The groundwater nitrate problem. British Geological Survey Hydrogeology Research Report 86/2. 1986.

Foster SSD, Kelly DP, James R. The evidence for zones of biodenitrification in British aquifers. In: Brierly CL, editor. Planetary Ecology. Van Nostrand Reinhold, New York, 1985, pp. 356-369.

Fowler D, Cape J, Unsworth M. Deposition of atmospheric pollutants on forests. Philosophical Transactions of the Royal Society of London Series B-Biological Sciences. 1989; 324: 247-265.

Fowler D, O’Donoghue M, Muller JBA, Smith RI, Dragosits U, Skiba U, et al. A chronology of nitrogen deposition in the UK between 1900 and 2000. Water, Air and Soil Pollution: Focus 2005; 4: 9-23.

Francis AJ, Slater JM, Dodge CJ. Denitrification in deep subsurface sediments. Geomicrobiology 1989; 7: 103-116.

Gale IN, Marks RJ, Darling WG, West JM.Bacterial denitrification in aquifers. Evidence from the unsaturated zone and the unconfined Chalk and Sherwood Sandstone aquifers. National Rivers Authority R\&D Note 215. 1994.

Galloway JN, Townsend AR, Erisman JW, Bekunda M, Cai Z, Freney JR, et al. Transformation of the nitrogen cycle: recent trends, questions, and potential solutions. Science 2008; 320: 889-892.

Gehman Jr HM. Organic matter in limestones. Geochimica et Cosmochimica Acta 1962; 26: 885-897.

Gooddy DC, Darling WG.Contaminant attenuation through glacial drift overlying the Chalk aquifer in southern East Anglia, UK. IAEA Technical Report 1618. Application of Isotopes to the Assessment of Pollutant Behaviour in the Unsaturated Zone for Groundwater Protection 2009.

Gooddy DC, Hinsby K. Organic quality of groundwaters. In: Edmunds W, Shand P, editors. Natural Groundwater Quality. Blackwell, 2008, pp. 22-58.

Gooddy DC, Lapworth DJ, Ascott MJ, Bennett SA, Heaton TH, Surridge BW. Isotopic fingerprint for phosphorus in drinking water supplies. Environmental Science \& Technology 2015; Early view.

Goulding KWT, Bailey NJ, Bradbury NJ, Hargreaves P, Howe M, Murphy DV, et al. Nitrogen deposition and its contribution to nitrogen cycling and associated soil processes. New Phytologist 1998; 139: 4958.

Griffiths KJ, Shand P, Ingram J.Baseline Series Report 2: The Permo-Triassic Sandstones of West Cheshire and the Wirral. British Geological Survey Commissioned Report CR/02/109N \& Environment Agency Report NC/99/74/2 2003a.

Griffiths KJ, Shand P, Ingram J.Baseline Series Report 8: The Permo-Triassic Sandstones Manchester and East Cheshire. British Geological Survey Commissioned Report CR/03/265N \& Environment Agency Report NC/99/74/8 2003b.

Griffiths KJ, Shand P, Ingram J.Baseline Series Report 19: The Permo-Triassic Sandstones of Liverpool and Rufford. British Geological Survey Commissioned Report CR/05/161N \& Environment Agency Report NC/99/74/19 2005.

Griffiths KJ, Shand P, Marchant P, Peach DW.Baseline Series Report 23: The Lincolnshire Limestone. British Geological Survey Commissioned Report CR/05/060N \& Environment Agency Report NC/99/74/23 2006.

Hansen B, Dalgaard T, Thorling L, Sørensen B, Erlandsen M. Regional analysis of groundwater nitrate concentrations and trends in Denmark in regard to agricultural influence. Biogeosciences 2012; 9: 3277-3286.

Haygarth PM, Chapman PJ, Jarvis SC, Smith RV. Phosphorus budgets for two contrasting grassland farming systems in the UK. Soil Use and Management 1998; 14: 160-167.

Heathwaite AL, Dils RM. Characterising phosphorus loss in surface and subsurface hydrological pathways. Science of the Total Environment 2000; 251-252: 523-538. 
Hiscock KM, Iqbal T, Feast NA, Dennis PF. Isotope and reactive transport modelling of denitrification in the Lincolnshire Limestone aquifer, eastern England. Quarterly Journal of Engineering Geology and Hydrogeology 2011; 44: 93-108.

Holman IP, Howden N, Whelan M, Bellamy P, Rivas-Casado M, Willby N.An improved understanding of phosphorus origin, fate and transport within groundwater and the significance for associated receptors. SNIFFER Final Report Project WFD85. 2008a.

Holman IP, Howden NJK, Bellamy P, Willby N, Whelan MJ, Rivas-Casado M. An assessment of the risk to surface water ecosystems of groundwater $\mathrm{P}$ in the UK and Ireland. Science of the Total Environment 2010; 408: 1847-1857.

Holman IP, Whelan MJ, Howden NJK, Bellamy PH, Willby NJ, Rivas-Casado M, et al. Phosphorus in groundwater-an overlooked contributor to eutrophication? Hydrological Processes 2008b; 22: 5121-5127.

Hornung M, Sutton M, Wilson R.Mapping and modelling of critical loads for nitrogen - a workshop report. Institute of Terrestrial Ecology 1995.

Howden NJK, Burt TP. Statistical analysis of nitrate concentrations from the Rivers Frome and Piddle (Dorset, UK) for the period 1965-2007. Ecohydrology 2009; 2: 55-65.

Jenkinson D. The impact of humans on the nitrogen cycle, with focus on temperate arable agriculture. Plant and Soil 2001; 228: 3-15.

Jones A, Smart P. Spatial and temporal changes in the structure of groundwater nitrate concentration time series (1935-1999) as demonstrated by autoregressive modelling. Journal of Hydrology 2005; 310: 201-215.

Jones DL, Shannon D, Murphy DV, Farrar J. Role of dissolved organic nitrogen (DON) in soil N cycling in grassland soils. Soil Biology and Biochemistry 2004; 36: 749-756.

Kaiser K, Guggenberger G, Haumaier L, Zech W. The composition of dissolved organic matter in forest soil solutions: changes induced by seasons and passage through the mineral soil. Organic Geochemistry 2002; 33: 307-318.

Kartal B, Kuypers MM, Lavik G, Schalk J, Op den Camp HJ, Jetten MS, et al. Anammox bacteria disguised as denitrifiers: nitrate reduction to dinitrogen gas via nitrite and ammonium. Environmental Microbiology 2007; 9: 635-642.

Kennedy WJ, Garrison RE. Morphology and genesis of nodular phosphates in the Cenomanian Glauconitic Marl of south-east England. Lethaia 1975; 8: 339-360.

Khamis K, Sorensen J, Bradley C, Hannah D, Lapworth DJ, Stevens R. In situ tryptophan-like fluorometers: assessing turbidity and temperature effects for freshwater applications. Environmental Science: Processes \& Impacts 2015; 17: 740-752.

Kinniburgh DG, Gale IN, Gooddy DC, Darling WG, Marks RJ, Gibbs BR, et al.Denitrification in the unsaturated zones of the British Chalk and Sherwood Sandstone aquifers. Btitish Geological Survey Technical Report WD/99/2. 1999.

Krause S, Heathwaite AL, Miller F, Hulme P, Crowe A. Groundwater-dependent wetlands in the UK and Ireland: controls, functioning and assessing the likelihood of damage from human activities. Water Resources Management 2007; 21: 2015-2025.

Kroeger K, Cole M, Valiela I. Groundwater-transported dissolved organic nitrogen exports from coastal watersheds. Limnology and Oceanography 2006; 51: 2248-2261.

Lapworth D, Gooddy D, Allen D, Old G. Understanding groundwater, surface water, and hyporheic zone biogeochemical processes in a Chalk catchment using fluorescence properties of dissolved and colloidal organic matter. Journal of Geophysical Research: Biogeosciences (2005-2012) 2009; 114.

Lapworth DJ, Gooddy DC. Source and persistence of pesticides in a semi-confined chalk aquifer of southeast England. Environmental Pollution 2006; 144: 1031-1044.

Lapworth DJ, Gooddy DC, Butcher AS, Morris BL. Tracing groundwater flow and sources of organic carbon in sandstone aquifers using fluorescence properties of dissolved organic matter (DOM). Applied Geochemistry 2008a; 23: 3384-3390.

Lapworth DJ, Gooddy DC, Jarvie HP. Understanding phosphorus mobility and bioavailability in the hyporheic zone of a chalk stream. Water, Air, \& Soil Pollution 2011; 218: 213-226.

Lapworth DJ, Gooddy DC, Kent F, Heaton TH, Cole SJ, Allen D. A combined geochemical and hydrological approach for understanding macronutrient sources. Journal of Hydrology 2013; 500: 226-242.

Lapworth DJ, Shand P, Abesser C, Darling WG, Haria AH, Evans CD, et al. Groundwater nitrogen composition and transformation within a moorland catchment, mid-Wales. Science of the Total Environment 2008b; 390: 241-254. 
Lawrence AR, Foster SSD. Denitrification in a limestone aquifer in relation to the security of low-nitrate groundwater supplies. Journal of the Institution of Water Engineers and Scientists, 1986; 40: 159172.

Lecher AL, Mackey K, Kudela R, Ryan J, Fisher A, Murray J, et al. Nutrient loading through submarine groundwater discharge and phytoplankton growth in Monterey Bay. Environmental Science \& Technology 2015; 49: 6665-73.

Liang L, Singer PC. Factors influencing the formation and relative distribution of haloacetic acids and trihalomethanes in drinking water. Environmental Science \& Technology 2003; 37: 2920-2928.

Limbrick KJ. Baseline nitrate concentration in groundwater of the Chalk in south Dorset, UK. Science of the Total Environment 2003; 314-316: 89-98.

MacDonald AM, Darling WG, Ball DF, Oster H. Identifying trends in groundwater quality using residence time indicators: an example from the Permian aquifer of Dumfries, Scotland. Hydrogeology Journal 2003; 11: 504-517.

MacDonald AM, Lapworth DJ, Hughes AG, Auton CA, Maurice L, Finlayson A, et al. Groundwater, flooding and hydrological functioning in the Findhorn floodplain, Scotland. Hydrology Research 2014; 45: 755-773.

MacDonald AM, Ó Dochartaigh BE, Kinniburgh DG, Darling WG.Baseline Scotland: groundwater chemistry of southern Scotland. British Geological Survey Open Report OR/08/062 2008.

MacDonald AM, Robins NS, Ball DF, O Dochartaigh BE. An overview of groundwater in Scotland. Scottish Journal of Geology 2005; 41: 3-11.

Magnani F, Mencuccini M, Borghetti M, Berbigier P, Berninger F, Delzon S, et al. The human footprint in the carbon cycle of temperate and boreal forests. Nature 2007; 447: 849-851.

Mendizabal I, Baggelaar PK, Stuyfzand PJ. Hydrochemical trends for public supply well fields in The Netherlands (1898-2008), natural backgrounds and upscaling to groundwater bodies. Journal of Hydrology 2012; 450: 279-292.

Milne CJ, Kinniburgh DG.Geochemical properties of aquifers and other geological formations in the UK. British Geological Survey Commissioned Report CR/06/216N and Environment Agency Science report SC030110/SR 2006.

Moreau M, Shand P, Wilton N, Brown S, Allen DJ.Baseline Series Report 12: The Devonian aquifer of South Wales and Herefordshire. British Geological Survey Commissioned Report CR/04/185N \& Environment Agency Report NC/99/74/12 2004.

Neal C, Robson AJ, Neal M, Reynolds B. Dissolved organic carbon for upland acidic and acid sensitive catchments in mid-Wales. Journal of Hydrology 2005; 304: 203-220.

Neumann I, Brown S, Smedley PL, Besien T.Baseline Series Report 7: The Great and Inferior Oolite of the Cotswolds District. British Geological Survey Commissioned Report CR/03/202N \& Environment Agency Report NC/99/74/7 2003.

Neumann I, Cobbing J, Tooth AF, Shand P.Baseline Series Report 15: The Palaeogene of the Wessex Basin. British Geological Survey Commissioned Report CR/04/254N \& Environment Agency Report NC/99/74/15 2004.

Ó Dochartaigh BE, Smedley PL, MacDonald AM, Darling WG.Baseline Scotland: the Lower Devonian aquifer of Strathmore. British Geological Survey Commissioned Report CR/06/250N 2006.

Ó Dochartaigh BE, Smedley PL, MacDonald AM, Darling WG.Baseline Scotland: groundwater chemistry of the Old Red Sandstone of the Moray Firth area. British Geological Survey Open Report OR/10/031 2010.

Ó Dochartaigh BE, Smedley PL, MacDonald AM, Darling WG, S H.Baseline Scotland: groundwater chemistry of the Carboniferous sedimentary aquifers of the Midland Valley. British Geological Survey Open Report OR/11/021 2011.

Oenema 0, Boers P, Van Eerdt M, Fraters B, Van der Meer H, Roest C, et al. Leaching of nitrate from agriculture to groundwater: the effect of policies and measures in the Netherlands. Environmental Pollution 1998; 102: 471-478.

Oenema 0, van Liere L, Schoumans 0. Effects of lowering nitrogen and phosphorus surpluses in agriculture on the quality of groundwater and surface water in the Netherlands. Journal of Hydrology 2005; 304: 289-301.

Osenbrück K, Fiedler S, Knöller K, Weise SM, Sültenfuß J, Oster H, et al. Timescales and development of groundwater pollution by nitrate in drinking water wells of the Jahna-Aue, Saxonia, Germany. Water Resources Research 2006; 42.

Owen HG. The Gault-Lower Greensand Junction and the Lower Gault of the Maidstone By-Pass (East Section), Kent. Proceedings of the Geologists' Association, 1960; 71 364-378. 
Pabich W, Valiela I, Hemond H. Relationship between DOC concentration and vadose zone thickness and depth below water table in groundwater of Cape Cod, U.S.A. Biogeochemistry 2001; 55: 247-268.

Pacey NR. The mineralogy, geochemistry and origin of pelletal phosphates in the English Chalk. Chemical Geology 1985; 48: 243-256.

Pacey NR. Organic matter in Cretaceous chalks from eastern England. Chemical Geology 1989; 75: 191-208.

Peach DW, Shand P, Gooddy DC, Abesser CA, Bloomfield JP, Gallagher A.Hydrogeology and hydrochemistry of the Pang and Lambourn catchments. British Geological Survey Commissioned Report CR/06/46N. 2006.

Pretty J, Hildrew A, Trimmer M. Nutrient dynamics in relation to surface-subsurface hydrological exchange in a groundwater fed chalk stream. Journal of Hydrology 2006; 330: 84-100.

Puckett L. Hydrogeologic controls on the transport and fate of nitrate in ground water beneath riparian buffer zones: results from thirteen studies across the United States. Water Science \& Technology 2004; 49: 47-53.

Rhymes J, Jones L, Lapworth D, White D, Fenner N, McDonald J, et al. Using chemical, microbial and fluorescence techniques to understand contaminant sources and pathways to wetlands in a conservation site. Science of the Total Environment 2015; 511: 703-710.

Ritson JP, Bell M, Graham NJ, Templeton MR, Brazier RE, Verhoef A, et al. Simulated climate change impact on summer dissolved organic carbon release from peat and surface vegetation: Implications for drinking water treatment. Water Research 2014; 67: 66-76.

Rivett MO, Smith JWN, Buss SR, Morgan P. Nitrate occurrence and attenuation in the major aquifers of England and Wales. Quarterly Journal of Engineering Geology and Hydrogeology 2007; 40: 335352.

Roberts S, McArthur J. Surface/groundwater interactions in a UK limestone aquifer. Gambling with Groundwater-Physical, Chemical and Biological Aspects of Aquifer-Stream Relations, American Institute of Hydrology, St Paul, MN 1998: 125-130.

Robins NS. The quality of shallow groundwaters in Northern Ireland. Water and Environment Journal 1998; 12: 163-169.

Robins NS. Groundwater quality in Scotland: major ion chemistry of the key groundwater bodies. Science of the Total Environment 2002; 294: 41-56.

Robins NS, Shand P, Merrin PD. Shallow groundwater in drift and Lower Palaeozoic bedrock: the Afon Teifi valley in west Wales. In: Robins NS, Misstear BDR, editors. Groundwater in the Celtic Regions: Studies in Hard Rock and Quaternary Hydrogeology. Special Publication 182. Geological Society, London, 2000, pp. 123-131.

Rodellas V, Garcia-Orellana J, Tovar-Sánchez A, Basterretxea G, López-Garcia JM, Sánchez-Quiles D, et al. Submarine groundwater discharge as a source of nutrients and trace metals in a Mediterranean bay (Palma Beach, Balearic Islands). Marine Chemistry 2014; 160: 56-66.

Roy S, Speed C, Bennie J, Swift R, Wallace P. Identifying the significant factors that influence temporal and spatial trends in nitrate concentrations in the Dorset and Hampshire Basin Chalk aquifer of Southern England. Quarterly Journal of Engineering Geology and Hydrogeology 2007; 40: 377-392.

Rozemeijer J, Broers H. The groundwater contribution to surface water contamination in a region with intensive agricultural land use (Noord-Brabant, The Netherlands). Environmental Pollution 2007; 148: 695-706.

Sánchez-Pérez JM, Vervier P, Garabétian F, Sauvage S, Loubet M, Rols JL, et al. Nitrogen dynamics in the shallow groundwater of a riparian wetland zone of the Garonne, SW France: nitrate inputs, bacterial densities, organic matter supply and denitrification measurements. Hydrology and Earth System Sciences Discussions 2003; 7: 97-107.

Shand P, Abesser C, Farr G, Wilton N, Lapworth DJ, Gooddy DC, et al.Baseline Series Report 17: The Ordovician annd Silurian metasediment aquifers of Central and South Wales. British Geological Survey Commissioned Report CR/05/255N \& Environment Agency Report NC/99/74/17 2005.

Shand P, Ander L, Griffiths KJ, Doherty P, Lawrence AR.Baseline Series Report 11: The Bridport Sands of Dorset and Somerset. British Geological Survey Commissioned Report CR/04/166N \& Environment Agency Report NC/99/74/11 2004.

Shand P, Cobbing J, Tyler-Whittle R, Tooth AF, Lancaster A.Baseline Series Report 9: The The Lower Greensand of Southern England. British Geological Survey Commissioned Report CR/03/273N \& Environment Agency Report NC/99/74/9 2003a.

Shand P, Edmunds WM, Lawrence AR, Smedley PL, Burke S.The natural (baseline) quality of groundwater in England and Wales. British Geological Survey Research Report RR/07/06 \& Environment Agency Technical Report NC/99/74/24. 2007. 
Shand P, Tyler-Whittle R, Besien T, Peach DW, Lawrence AR, Lewis HO.Baseline Series Report 6: The Chalk of the Colne and Lee River catchments. British Geological Survey Commissioned Report CR/03/069N \& Environment Agency Report NC/99/74/6 2003b.

Shand P, Tyler-Whittle R, Morton M, Simpson E, Lawrence AR, Pacey J, et al.Baseline Series Report 1: The Triassic Sandstones of the Vale of York. British Geological Survey Commissioned Report CR/02/102N \& Environment Agency Report NC/99/74/1 2002.

Singer P. Humic substances as precursors for potentially harmful disinfection by-products. Water Science and Technology 1999; 40: 25-30.

Smedley PL, Allen DJ.Baseline Series Report 16: The granites of South-West England. British Geological Survey Commissioned Report CR/04/255N \& Environment Agency Report NC/99/74/16 2004.

Smedley PL, Griffiths KJ, Tyler-Whittle R, Hargreaves R, Lawrence AR, T B.Baseline Series Report 5: The Chalk of the North Downs, kent and East Surrey. British Geological Survey Commissioned Report CR/03/033N \& Environment Agency Report NC/99/74/5 2003.

Smedley PL, Neumann I, Brown S.Baseline Series Report 20: The Permo-Triassic Sandstone aquifer of Shropshire. British Geological Survey Commissioned Report CR/05/061N \& Environment Agency Report NC/99/74/20 2005.

Smedley PL, Neumann I, Farrell R.Baseline Series Report 10: The The Chalk aquifer of Yorkshire and Nortth Humberside. British Geological Survey Commissioned Report CR/04/128N \& Environment Agency Report NC/99/74/10 2004.

Smedley PL, Ó Dochartaigh BE, MacDonald AM, Darling WG.Baseline Scotland: groundwater chemistry of Aberdeenshire. British Geological Survey Open Report OR/09/065 2009.

Smil V. Phosphorus in the environment: natural flows and human interferences. Annual Review of Energy and the Environment 2000; 25: 53-88.

Smith B, Stuart ME, Vickers BP, Peachey D.The characterisation of organics from the natural analogues site at Broubster, Caithness., British Geological Survey Technical Report WE/89/33 1990.

Smith J, Lerner D. Geomorphologic control on pollutant retardation at the groundwater-surface water interface. Hydrological Processes 2008; 22: 4679-4694.

Smith JWN, Surridge BWJ, Haxton TH, Lerner DN. Pollutant attenuation at the groundwater-surface water interface: A classification scheme and statistical analysis using national-scale nitrate data. Journal of Hydrology 2009; 369: 392-402.

Smolders AJP, Lucassen ECHET, Bobbink R, Roelofs JGM, Lamers LPM. How nitrate leaching from agricultural lands provokes phosphate eutrophication in groundwater fed wetlands: the sulphur bridge. Biogeochemistry 2009; 98: 1-7.

Sorensen JP, Maurice L, Edwards FK, Lapworth DJ, Read DS, Allen D, et al. Using boreholes as windows into groundwater ecosystems. PloS one 2013; 8: e70264.

Starr RC, Gillham RW. Denitrification and organic carbon availability in two aquifers. Groundwater 1993; 31: 934-947.

Strebel O, Duynisveld W, Böttcher J. Nitrate pollution of groundwater in western Europe. Agriculture, ecosystems \& environment 1989; 26: 189-214.

Stuart ME.Organic matter in British aquifers. British Geological Survey Technical Report WD/91/5 \& Environment Agency R\&D Report 129/2/ST 1991.

Stuart ME, Chilton PJ, Kinniburgh DG, Cooper DM. Screening for long-term trends in groundwater nitrate monitoring data. Quarterly Journal of Engineering Geology and Hydrogeology 2007; 40: 361-376.

Stuart ME, Gooddy DC, Bloomfield JP, Williams AT. A review of the impact of climate change on future nitrate concentrations in groundwater of the UK. Science of the Total Environment 2011; 409: 2859-2873.

Stuart ME, Smedley PL.Baseline groundwater chemistry: the Chalk aquifer of Hampshire. British Geological Survey Open Report OR/09/052 2009.

Townsend A, Braswell B, Holland E, Penner J. Spatial and temporal patterns in terrestrial carbon storage due to deposition of fossil fuel nitrogen. Ecological applications 1996; 6: 806-814.

Tye AM, Lapworth DJ. Characterising changes in fluorescence properties of dissolved organic matter and links to N cycling in agricultural floodplains. Agriculture, Ecosystems and Environment 2016; 221: 245-257.

Tyler-Whittle R, Brown S, Shand P.Baseline Series Report 3: The Permo-Triassic Sandstones of South Staffordshire and North Worcestershire. British Geological Survey Commissioned Report CR/02/119N \& Environment Agency Report NC/99/74/3 2002.

Van Kessel C, Clough T, van Groenigen JW. Dissolved organic nitrogen: an overlooked pathway of nitrogen loss from agricultural systems? Journal of Environmental Quality 2009; 38: 393-401. 
Vitousek PM, Aber JD, Howarth RW, Likens GE, Matson PA, Schindler DW, et al. Human alteration of the global nitrogen cycle: causes and consequences. Ecological Applications 1997; 7: 737-750.

Waldrop MP, Zak DR, Sinsabaugh RL, Gallo M, Lauber C. Nitrogen deposition modifies soil carbon storage through changes in microbial enzymatic activity. Ecological applications 2004; 14: 1172-1177.

Wang L, Stuart M, Bloomfield J, Butcher A, Gooddy D, McKenzie A, et al. Prediction of the arrival of peak nitrate concentrations at the water table at the regional scale in Great Britain. Hydrological Processes 2012; 26: 226-239.

Watts G, Battarbee RW, Bloomfield JP, Crossman J, Daccache A, Durance I, et al. Climate change and water in the UK-past changes and future prospects. Progress in Physical Geography 2015; 39: 6-28.

West JM, Chilton PJ. Aquifers as environments for microbiological activity. Quarterly Journal of Engineering Geology and Hydrogeology 1997; 30: 147-154.

Whitelaw K, Edwards RA. Carbohydrates in the unsaturated zone of the Chalk, England. Chemical Geology 1980; 29: 281-291.

Withers P, Edwards A, Foy R. Phosphorus cycling in UK agriculture and implications for phosphorus loss from soil. Soil Use and Management 2001; 17: 139-149. 
Table 1 Summary of baseline concentrations of nitrogen species in groundwater. Data in italics for confined aquifers

\begin{tabular}{|c|c|c|c|c|c|c|c|c|c|c|c|c|c|c|c|c|c|c|c|c|}
\hline \multirow{3}{*}{$\begin{array}{l}\text { Aquifer } \\
\text { group }\end{array}$} & \multirow{3}{*}{ Area } & \multicolumn{18}{|c|}{ Concentration (mg/L) } & \multirow{3}{*}{ Reference } \\
\hline & & \multicolumn{6}{|c|}{$\mathrm{NO}_{3}-\mathrm{N}$} & \multicolumn{6}{|c|}{$\mathrm{NO}_{2}-\mathrm{N}$} & \multicolumn{6}{|c|}{$\mathrm{NH}_{4}-\mathrm{N}$} & \\
\hline & & Min & Mean & Max & P50 & P95 & P97.7 & Min & Mean & Max & P50 & P95 & P97.7 & Min & Mean & Max & P50 & P95 & P97.7 & \\
\hline \multirow{2}{*}{ Quaternary } & Rheidol & 0.20 & 4.7 & 10.5 & 4.0 & & 10.3 & 0.001 & 0.003 & 0.006 & 0.002 & & 0.006 & $<0.003$ & 0.035 & 0.134 & $<0.003$ & & 0.125 & \multirow{2}{*}{$\begin{array}{l}\text { Shand et al. } \\
(2005)\end{array}$} \\
\hline & Teifi & 0.54 & 2.27 & 4.34 & 1.99 & & 4.27 & & & & & & & $<0.010$ & 0.033 & 0.070 & 0.030 & & 0.069 & \\
\hline \multirow{10}{*}{ Chalk } & $\begin{array}{l}\text { Yorkshire/ } \\
\text { Humber }\end{array}$ & $<0.5$ & 9.5 & 33.2 & 8.81 & & 20.1 & $<0.01$ & 6 & 0.270 & $<0.01$ & & 0.02 & $<0.003$ & 20 & & $<0.03$ & & 0.09 & \multirow{2}{*}{$\begin{array}{l}\text { Smedley et al. } \\
(2004)\end{array}$} \\
\hline & $(Y / H$ confined $)$ & $<0.2$ & 0.20 & 1.2 & $<0.5$ & & 0.7 & $<0.003$ & 0.054 & 1.01 & $<0.01$ & & 0.560 & $<0.30$ & 1.450 & 10.6 & 0.880 & & 6.84 & \\
\hline & North Norfolk & 0.001 & 0.09 & 21.8 & 3.6 & 14 & 17.3 & 0.0015 & 0.09 & 4.07 & 0.34 & 0.006 & 1.99 & 0.0005 & 0.0005 & 0.01 & 0.005 & & 0.01 & \multirow{2}{*}{$\begin{array}{l}\text { Ander et al. } \\
(2006) \\
\text { Ander et al. } \\
(2004)\end{array}$} \\
\hline & Great Ouse & 0.287 & 10.3 & 38.4 & 9.5 & 18.8 & 25.0 & $<0.001$ & 0.019 & 0.101 & 0.006 & 0.087 & 0.093 & $<0.003$ & 0.011 & 0.17 & $<0.003$ & 0.074 & 0.088 & \\
\hline & Colne/Lee & 3.2 & 6.4 & 11.2 & 5.9 & 9.8 & 10.1 & $<0.001$ & 0.006 & 0.053 & 0.002 & 0.015 & 0.038 & $<0.003$ & 0.017 & 0.150 & 0.015 & & 0.060 & \multirow{2}{*}{$\begin{array}{l}\text { Shand et al. } \\
(2003 \mathrm{~b})\end{array}$} \\
\hline & (C/L confined $)$ & $<0.01$ & 0.265 & 2.18 & 0.1 & & 1.867 & $<0.001$ & 0.004 & 0.021 & 0.002 & & 0.016 & 0.004 & 0.408 & 1.66 & 0.240 & & 1.37 & \\
\hline & North Downs & 0.2 & & 28.2 & 6.4 & 14.2 & 22.5 & $<0.003$ & & 0.008 & $<0.005$ & 0.005 & 0.007 & $<0.009$ & & 12 & $<0.05$ & & 0.016 & \multirow{2}{*}{$\begin{array}{l}\text { Smedley et al. } \\
(2003)\end{array}$} \\
\hline & ( $N$ D confined) & $<0.01$ & & 0.42 & $<0.3$ & & 0.38 & $<0.002$ & & 0.005 & $<0.005$ & & 0.004 & $<0.01$ & & 4.40 & 0.56 & & 4.18 & \\
\hline & Hampshire & $<0.05$ & 6.58 & 12.6 & 6.53 & 10.7 & & $<0.0006$ & 0.0017 & 0.01 & 0.0005 & 0.008 & & $<0.005$ & 0.0092 & 0.066 & 0.0012 & 0.0637 & & $\begin{array}{l}\text { Stuart and } \\
\text { Smedley } \\
(2009)\end{array}$ \\
\hline & Dorset & 0.05 & & 12.0 & 6.2 & 9.9 & 11.2 & $<0.001$ & & 0.057 & $<0.001$ & 0.04 & 0.043 & $<0.003$ & & 0.310 & 0.011 & 0.076 & 0.131 & $\begin{array}{l}\text { Edmunds et al. } \\
(2002)\end{array}$ \\
\hline \multirow{7}{*}{ Limestone } & $\begin{array}{l}\text { Oxford \& Wilts } \\
\text { Corallian } \\
\text { Vale of } \\
\text { Pickering } \\
\text { Corallian }\end{array}$ & $\begin{array}{c}0.1 \\
0.086\end{array}$ & $\begin{array}{l}4.47 \\
7.75\end{array}$ & $\begin{array}{l}29.5 \\
24.4\end{array}$ & $\begin{array}{c}0.25 \\
5.7\end{array}$ & $\begin{array}{l}18.5 \\
22.6\end{array}$ & 22.1 & 0 & 0.04 & 0.53 & 0 & 0.05 & 0.42 & 0.02 & 0.19 & 0.80 & 0.07 & 0.64 & 0.70 & $\begin{array}{l}\text { Cobbing et al. } \\
\text { (2004) } \\
\text { Bearcock et al. } \\
(2015)\end{array}$ \\
\hline & Cotswolds & $<0.004$ & 8.27 & 18.2 & 8.16 & 15.8 & 16.8 & $<0.002$ & $<0.002$ & 0.02 & $<0.002$ & 0.009 & 0.01 & $<0.004$ & 0.03 & 0.61 & 0.03 & 0.03 & 0.26 & $\begin{array}{l}\text { Neumann et al. } \\
(2003)\end{array}$ \\
\hline & Lincolnshire & 0.100 & 10.8 & 20.7 & 11.5 & 19.53 & 20.1 & 0.0004 & 0.004 & 0.012 & 0.002 & 0.007 & 0.010 & $<0.003$ & 0.027 & 0.210 & 0.015 & 0.084 & 0.132 & \multirow{2}{*}{$\begin{array}{l}\text { Griffiths et al. } \\
(2006)\end{array}$} \\
\hline & (Lincs confined) & $<0.003$ & 0.307 & 3.47 & $<0.003$ & 1.69 & 2.65 & 0.0004 & 0.002 & 0.0071 & 0.0008 & 0.005 & 0.006 & $<0.003$ & 0.005 & 1.81 & 0.220 & 1.132 & 1.38 & \\
\hline & Magnesian & $<0.002$ & 3.32 & 20.5 & 1.36 & 0.029 & & $<0.0023$ & 0.0082 & 0.395 & 0.001 & 0.029 & & & & & & & & \multirow{3}{*}{$\begin{array}{l}\text { Bearcock and } \\
\text { Smedley } \\
(2009) \\
\text { Abesser et al. } \\
(2005 b) \\
\text { Abesser and } \\
\text { Smedley } \\
(2008)\end{array}$} \\
\hline & $\begin{array}{l}\text { Carboniferous } \\
\text { Northern }\end{array}$ & $<1$ & 1.64 & 46.1 & $<1$ & 4.9 & 5.46 & $<0.02$ & $<0.02$ & 0.220 & $<0.02$ & 0.085 & 0.098 & $<0.05$ & 0.25 & 11.3 & $<0.05$ & 0.94 & 1.28 & \\
\hline & \begin{tabular}{|l} 
Carboniferous \\
Derby
\end{tabular} & $<0.05$ & 3.22 & 12.6 & 3.06 & 8.5 & & $<0.0007$ & 0.0023 & 0.087 & 0.0004 & 0.003 & & $<0.006$ & 0.031 & 0.434 & 0.003 & 0.163 & & \\
\hline
\end{tabular}




\begin{tabular}{|c|c|c|c|c|c|c|c|c|c|c|c|c|c|c|c|c|c|c|c|c|}
\hline \multirow{3}{*}{$\begin{array}{l}\text { Aquifer } \\
\text { group }\end{array}$} & \multirow{3}{*}{ Area } & \multicolumn{18}{|c|}{ Concentration (mg/L) } & \multirow{3}{*}{ Reference } \\
\hline & & \multicolumn{6}{|c|}{$\mathrm{NO}_{3}-\mathrm{N}$} & \multicolumn{6}{|c|}{$\mathrm{NO}_{2}-\mathrm{N}$} & \multicolumn{6}{|c|}{$\mathrm{NH}_{4}-\mathrm{N}$} & \\
\hline & & Min & Mean & Max & P50 & P95 & P97.7 & Min & Mean & Max & P50 & P95 & P97.7 & Min & Mean & Max & P50 & P95 & P97.7 & \\
\hline \multirow{7}{*}{$\begin{array}{l}\text { Permo- } \\
\text { Triassic } \\
\text { Sandstone }\end{array}$} & Vale of York & $<0.002$ & 4.11 & 41.1 & 0.053 & 21.7 & 31.5 & $<0.001$ & 0.024 & 0.514 & 0.003 & 0.0488 & 0.319 & $<0.003$ & 0.192 & 3.01 & 0.011 & 0.46 & 2.71 & $\begin{array}{l}\text { Shand et al. } \\
(2002)\end{array}$ \\
\hline & $\begin{array}{l}\text { Liverpool \& } \\
\text { Rufford }\end{array}$ & 0.001 & 3.48 & 21.3 & 1.5 & 13.2 & 18.73 & 0.001 & 0.008 & 0.112 & 0.002 & 0.036 & 0.043 & 0.002 & 0.14 & 2.31 & 0.02 & 0.31 & 0.62 & $\begin{array}{l}\text { Griffiths et al. } \\
(2005)\end{array}$ \\
\hline & $\begin{array}{l}\text { West Cheshire } \\
\text { \& Wirral }\end{array}$ & 0.025 & 5.0 & 31.7 & 3.3 & 16.9 & 21.0 & 0.001 & 0.021 & 0.657 & 0.01 & 0.1 & 0.135 & $<0.003$ & 0.159 & 5.3 & 0.025 & 0.47 & 1.4 & $\begin{array}{l}\text { Griffiths et al. } \\
(2003 a)\end{array}$ \\
\hline & $\begin{array}{l}\text { Manchester \& } \\
\text { East Cheshire }\end{array}$ & $<0.003$ & 1.6 & 33.4 & 0.3 & 6.7 & 8.9 & $<0.001$ & 0.0 & 0.1 & 0.0 & 0.1 & 0.1 & $<0.003$ & 0.2 & 5.4 & 0.0 & 0.4 & 1.7 & $\begin{array}{l}\text { Griffiths et al. } \\
(2003 b)\end{array}$ \\
\hline & $\begin{array}{l}\text { South } \\
\text { Staffordshire }\end{array}$ & 0.4 & 9.6 & 26.9 & 9.4 & 18.4 & 22.7 & $<0.001$ & 0.013 & 0.173 & 0.003 & 0.011 & 0.134 & $<0.003$ & 0.033 & 0.435 & 0.015 & 0.13 & 0.200 & $\begin{array}{l}\text { Tyler-Whittle } \\
\text { et al. (2002) }\end{array}$ \\
\hline & Shropshire & $<0.2$ & 8.2 & 50.8 & 6.3 & 17.8 & 28.9 & $<0.001$ & 0.004 & 0.096 & $<0.005$ & 0.011 & 0.031 & $<0.003$ & $<0.04$ & 0.31 & $<0.04$ & 0.1 & 0.18 & $\begin{array}{l}\text { Smedley et al. } \\
(2005)\end{array}$ \\
\hline & Otter & 1.58 & 9.55 & 29.5 & 7.88 & 21.2 & & $<0.003$ & & 0.0045 & & & & $<0.003$ & 0.118 & 0.19 & 0.0031 & 0.018 & & $\begin{array}{l}\text { Bearcock and } \\
\text { Smedley } \\
(2012)\end{array}$ \\
\hline \multirow{4}{*}{$\begin{array}{l}\text { Devonian } \\
\text { ORS }\end{array}$} & \begin{tabular}{|l} 
South Wales \& \\
Hereford
\end{tabular} & $<0.002$ & 4.05 & 15.6 & 2.15 & 12.7 & 13.3 & $<0.001$ & 0.002 & 0.033 & 0.001 & 0.008 & 0.009 & $<0.003$ & 0.018 & 0.150 & 0.009 & 0.06 & 0.093 & $\begin{array}{l}\text { Moreau et al. } \\
(2004)\end{array}$ \\
\hline & Moray Basin & $<0.05$ & & 21.7 & 0.058 & 12.0 & & $<0.001$ & & 0.052 & 0.0003 & 0.0337 & & $<0.01$ & & 2.18 & 0.0008 & 0.722 & & $\begin{array}{l}\text { ó Dochartaigh } \\
\text { et al. (2010) }\end{array}$ \\
\hline & $\begin{array}{l}\text { Strathmore, } \\
\text { Scotland }\end{array}$ & 0.2 & & 81 & 6.7 & & & $<0.0003$ & & 0.194 & 0.0029 & & & $<0.004$ & & 8.32 & $<0.004$ & & & $\begin{array}{l}\text { ó Dochartaigh } \\
\text { et al. (2006) }\end{array}$ \\
\hline & $\begin{array}{l}\text { Southern } \\
\text { Scotland }\end{array}$ & 0.163 & & 11.3 & 3.88 & & & 0.0002 & & 0.006 & 0.0011 & & & 0.0002 & & 0.018 & 0.0008 & & & $\begin{array}{l}\text { MacDonald et } \\
\text { al. (2008) }\end{array}$ \\
\hline \multirow{6}{*}{$\begin{array}{l}\text { Other } \\
\text { sandstone }\end{array}$} & Crag & 0.001 & 6.8 & 49 & 9.7 & 14 & 35 & 0.0015 & 0.008 & 2.6 & 0.207 & 0.0067 & 1.7 & 0.0005 & 0.0005 & 0.016 & 0.003 & & 0.014 & $\begin{array}{l}\text { Ander et al. } \\
(2006)\end{array}$ \\
\hline & $\begin{array}{l}\text { Thames } \\
\text { Palaeogene }\end{array}$ & $<0.02$ & 4.76 & 55.7 & 0.055 & 34.0 & & $<0.0001$ & 0.0174 & 0.347 & 0.0023 & 0.0487 & & $<0.01$ & 0.33 & 6.7 & 0.069 & 0.94 & & $\begin{array}{l}\text { Bearcock and } \\
\text { Smedley } \\
(2010)\end{array}$ \\
\hline & $\begin{array}{l}\text { Wessex } \\
\text { Palaeogene }\end{array}$ & $<0.2$ & 4.32 & 34.8 & $<0.2$ & 29.6 & 33.7 & $<0.004$ & 0.006 & 0.05 & $<0.004$ & 0.019 & 0.035 & $<0.03$ & 0.065 & 0.323 & 0.038 & 0.16 & 0.232 & $\begin{array}{l}\text { Neumann et al. } \\
(2004)\end{array}$ \\
\hline & Millstone Grit & $<1$ & 1.2 & 12.5 & $<1$ & 4.6 & 5.6 & $<0.02$ & $<0.02$ & 0.08 & $<0.02$ & 0.02 & 0.04 & $<0.02$ & 0.15 & 2.23 & $<0.05$ & 0.55 & 0.73 & $\begin{array}{l}\text { Abesser et al. } \\
(2005 a)\end{array}$ \\
\hline & $\begin{array}{l}\text { Lower } \\
\text { Greensand }\end{array}$ & $<0.003$ & 2.39 & 16.3 & 0.20 & 11.3 & 15.5 & $<0.001$ & 0.006 & 0.10 & 0.002 & 0.016 & 0.035 & $<0.003$ & 0.093 & 1.36 & 0.030 & 0.28 & 0.96 & $\begin{array}{l}\text { Shand et al. } \\
(2003 a)\end{array}$ \\
\hline & Bridport Sand & 0.009 & 5.0 & 42.7 & 4.9 & 13.8 & 16.7 & $<0.001$ & 0.007 & 0.08 & 0.002 & 0.024 & 0.048 & $<0.003$ & 0.014 & 0.14 & 0.010 & 0.03 & 0.068 & $\begin{array}{l}\text { Shand et al. } \\
(2004)\end{array}$ \\
\hline \begin{tabular}{|l|} 
Carbonif- \\
erous
\end{tabular} & Midland Valley & $<0.05$ & & 17.7 & & 3.71 & & $<0.02$ & & 6.3 & & & & $<0.01$ & & 1.75 & 0.036 & 0.957 & & $\begin{array}{l}\text { Ó Dochartaigh } \\
\text { et al. (2011) }\end{array}$ \\
\hline
\end{tabular}




\begin{tabular}{|c|c|c|c|c|c|c|c|c|c|c|c|c|c|c|c|c|c|c|c|c|}
\hline \multirow{4}{*}{$\begin{array}{l}\text { Aquifer } \\
\text { group }\end{array}$} & \multirow{3}{*}{ Area } & \multicolumn{18}{|c|}{ Concentration (mg/L) } & \multirow{3}{*}{ Reference } \\
\hline & & \multicolumn{6}{|c|}{$\mathrm{NO}_{3}-\mathrm{N}$} & \multicolumn{6}{|c|}{$\mathrm{NO}_{2}-\mathrm{N}$} & \multicolumn{6}{|c|}{$\mathrm{NH}_{4}-\mathrm{N}$} & \\
\hline & & Min & Mean & Max & P50 & P95 & P97.7 & Min & Mean & Max & P50 & P95 & P97.7 & Min & Mean & Max & P50 & P95 & P97.7 & \\
\hline & $\begin{array}{l}\text { Southern } \\
\text { Scotland }\end{array}$ & 0.007 & & 7.01 & 2.35 & & & 0.0002 & & 0.0097 & 0.0007 & & & & & & & & & $\begin{array}{l}\text { MacDonald et } \\
\text { al. (2008) }\end{array}$ \\
\hline \multirow{2}{*}{$\begin{array}{l}\text { Dalradian } \\
\text { and igneous }\end{array}$} & $\begin{array}{l}\text { Cornwall } \\
\text { Granite }\end{array}$ & & 6.35 & 33.3 & 5.35 & & 16.7 & & $<0.01$ & 0.085 & $<0.01$ & & 0.01 & $<0.02$ & $<0.03$ & 0.21 & $<0.03$ & & 0.049 & $\begin{array}{l}\text { Smedley and } \\
\text { Allen (2004) }\end{array}$ \\
\hline & Aberdeenshire & 0.052 & & 24.3 & 7.15 & 21.2 & & $<0.0003$ & & 0.009 & 0.002 & 0.005 & & $<0.01$ & & 0.17 & 0.006 & 0.092 & & $\begin{array}{l}\text { Smedley et al. } \\
(2009)\end{array}$ \\
\hline \multirow{6}{*}{ Palaeozoic } & $\begin{array}{l}\text { Plynlimon } \\
\text { Severn }\end{array}$ & $<0.01$ & 0.51 & 1.90 & 0.05 & & 1.85 & $<0.003$ & 0.010 & 0.049 & $<0.003$ & & 0.040 & $<0.010$ & 0.040 & 0.190 & 0.010 & & 0.150 & \multirow{6}{*}{$\begin{array}{l}\text { Shand et al. } \\
\text { (2005) }\end{array}$} \\
\hline & Plynlimon Wye & $<0.01$ & 0.09 & 0.97 & 0.02 & & 0.64 & $<0.003$ & 0.002 & 0.025 & $<0.003$ & & 0.017 & $<0.020$ & 0.077 & 0.663 & 0.020 & & 0.495 & \\
\hline & Teifi & $<0.09$ & 1.47 & 9.33 & 0.95 & & 7.01 & $<0.001$ & 0.003 & 0.010 & 0.002 & & 0.008 & $<0.010$ & 0.072 & 1.720 & $<0.010$ & & 0.769 & \\
\hline & \multirow{3}{*}{$\begin{array}{l}\text { Rheidol } \\
\text { Silurian S } \\
\text { Scotland } \\
\text { Ordovician S } \\
\text { Scot }\end{array}$} & $<0.1$ & 2.6 & 11.8 & 0.7 & & \multirow[t]{3}{*}{11.1} & 0.001 & 0.003 & 0.006 & 0.002 & & \multirow[t]{3}{*}{0.006} & $<0.003$ & 0.033 & 0.193 & 0.010 & & \multirow[t]{3}{*}{0.189} & \\
\hline & & 0.04 & & 15.5 & 3.88 & & & 0.00007 & & 0.0061 & 0.0013 & & & $<0.00005$ & & 0.0475 & 0.0006 & & & \\
\hline & & 0.19 & & 37.2 & 1.21 & & & 0.0003 & & 0.013 & 0.0022 & & & 0.0001 & & 3.985 & 0.0024 & & & \\
\hline
\end{tabular}


Table 2 Summary of estimated $\mathrm{NO}_{3}-\mathrm{N}$ concentrations for England and Wales for $\mathbf{1}^{\text {st }}$ January 2000 and trends (Stuart et al., 2007)

\begin{tabular}{|c|c|c|c|c|c|c|c|}
\hline \multirow[t]{2}{*}{ Aquifer } & \multicolumn{3}{|c|}{$\begin{array}{c}\mathrm{NO}_{3}-\mathrm{N} \text { concentration } \\
(\mathrm{mg} / \mathrm{L})\end{array}$} & \multicolumn{3}{|c|}{$\begin{array}{l}\mathrm{NO}_{3}-\mathrm{N} \text { trend } \\
(\mathrm{mg} / \mathrm{L} / \mathrm{a})\end{array}$} & \multirow[t]{2}{*}{$\mathbf{N}$} \\
\hline & Min & Median & Max & Min & Median & Max & \\
\hline Superficial gravels & 5.41 & 8.31 & 11.23 & -0.49 & -0.22 & 0.04 & 2 \\
\hline Chalk & 0.01 & 9.80 & 18.39 & -0.32 & 0.09 & 0.62 & 74 \\
\hline Lower Greensand & 9.01 & 11.53 & 14.05 & 0.13 & 0.14 & 0.14 & 2 \\
\hline Jurassic oolitic limestone & 6.46 & 11.67 & 16.38 & -0.30 & 0.01 & 0.39 & 11 \\
\hline Lincolnshire Limestone & 2.64 & 8.42 & 28.94 & -0.02 & 0.22 & 0.80 & 12 \\
\hline Lias & 0.00 & 0.00 & 0.01 & -0.01 & 0.00 & 0.00 & 5 \\
\hline Permo-Triassic sandstone & 1.51 & 10.81 & 40.84 & -0.22 & 0.10 & 0.45 & 41 \\
\hline Permian limestone & 0.08 & 1.91 & 17.06 & -0.24 & 0.04 & 0.96 & 43 \\
\hline Carboniferous limestone & & 7.56 & & & 0.10 & & 1 \\
\hline All & 0.00 & 8.84 & 40.84 & -0.49 & 0.08 & 0.96 & 191 \\
\hline
\end{tabular}


Table3 Other reported $\mathbf{N}$ concentrations and trends in UK groundwater

\begin{tabular}{|c|c|c|c|c|c|}
\hline Location & Aquifer & $\begin{array}{l}\text { No of } \\
\text { samples }\end{array}$ & $\begin{array}{l}\mathrm{NO}_{3}-\mathrm{N} \text { conc. } \\
\text { range }\end{array}$ & Observations & Reference \\
\hline East Anglia & Chalk & $\begin{array}{l}\text { Model of } 5 \\
\text { sites }\end{array}$ & & $\begin{array}{l}\mathrm{NO}_{3}-\mathrm{N} \text { increasing at } 0.05- \\
0.2 \mathrm{mg} / \mathrm{L} / \mathrm{yr} \text { under } \\
\text { arable land since } 1965\end{array}$ & $\begin{array}{l}\text { Carey and } \\
\text { Lloyd (1985) }\end{array}$ \\
\hline Berkshire & Chalk & $\begin{array}{l}\text { Profiles }+ \\
38 \text { pumped } \\
\text { samples }\end{array}$ & $\begin{array}{l}20-49 \mathrm{mg} / \mathrm{L} \mathrm{in} \\
\text { unconfined } \\
\text { aquifer }\end{array}$ & $\begin{array}{l}\text { Study along flow line into } \\
\text { confined aquifer where } \\
\mathrm{NO}_{3}-\mathrm{N}<0.2\end{array}$ & $\begin{array}{l}\text { Edmunds et } \\
\text { al. (1987) }\end{array}$ \\
\hline South Dorset & Chalk & $\begin{array}{l}\text { Historical } \\
\text { data since } \\
1894\end{array}$ & & $\begin{array}{l}100 \text {-year trend from } 1 \text { to } \\
9 \mathrm{mg} / \mathrm{L} \mathrm{NO}_{3}-\mathrm{N}\end{array}$ & $\begin{array}{l}\text { Limbrick } \\
\text { (2003) }\end{array}$ \\
\hline $\begin{array}{l}\text { Dorset and } \\
\text { Hampshire }\end{array}$ & Chalk & Model & $\begin{array}{l}30 \% \text { increase } \\
\text { over } 30 \text { years } \\
\text { Modelled rate } \\
0.12 \mathrm{mg} / \mathrm{L} / \mathrm{a}\end{array}$ & $\begin{array}{l}\text { Low concentrations (up } \\
\text { to5 mg/L } \mathrm{NO}_{3}-\mathrm{N} \text { ) } \\
\text { associated with Salisbury } \\
\text { Plain and Cranbourne } \\
\text { Chase. Arable and urban } \\
\text { with high concentrations. }\end{array}$ & $\begin{array}{l}\text { Roy et al. } \\
\text { (2007) }\end{array}$ \\
\hline East Anglia & $\begin{array}{l}\text { Quaternary, Crag, } \\
\text { Chalk, Lower } \\
\text { Greensand, Lower } \\
\text { Cretaceous, } \\
\text { Lincolnshire } \\
\text { Limestone, } \\
\text { Sherwood } \\
\text { Sandstone }\end{array}$ & 100 sources & $\begin{array}{l}33 \% \text { over } 50 \\
\mathrm{mg} / \mathrm{L} \mathrm{NO}_{3}(11.3 \\
\left.\mathrm{mg} / \mathrm{L} \text { as } \mathrm{NO}_{3}-\mathrm{N}\right)\end{array}$ & $\begin{array}{l}\text { Concentrations recess to } \\
\text { long-term rising baseline } \\
\text { in Chalk and to level } \\
\text { baseline in Lincolnshire } \\
\text { Limestone }\end{array}$ & $\begin{array}{l}\text { Beeson and } \\
\text { Cook }(2004)\end{array}$ \\
\hline Dumfries & $\begin{array}{l}\text { Permian } \\
\text { Sandstone }\end{array}$ & & $\begin{array}{l}\text { Pre-1950s } \\
\text { water } 2 \mathrm{mg} / \mathrm{L} \\
\text { modern water } 9 \\
\mathrm{mg} / \mathrm{L}\end{array}$ & $\begin{array}{l}\text { Concentration related to } \\
\% \text { of recent recharge }\end{array}$ & $\begin{array}{l}\text { MacDonald et } \\
\text { al. (2003) }\end{array}$ \\
\hline N E Scotland & $\begin{array}{l}\text { Devonian } \\
\text { Sandstone, } \\
\text { Quaternary } \\
\text { floodplain deposits }\end{array}$ & $\begin{array}{l}27 \\
\text { boreholes }\end{array}$ & $\begin{array}{l}<0.05-25.9 \\
\mathrm{mg} / \mathrm{L}\end{array}$ & $\begin{array}{l}\text { Evidence of } \\
\text { anthropogenic } \\
\text { contamination in the } \\
\text { Quaternary floodplain } \\
\text { deposits. Low } \mathrm{NO}_{3}-\mathrm{N} \\
\text { conc. in the sandstone } \\
\text { aquifer }\end{array}$ & $\begin{array}{l}\text { MacDonald et } \\
\text { al. (2014) }\end{array}$ \\
\hline
\end{tabular}


Table 4 Summary of baseline concentrations of TDP in groundwater. Data in italics for confined aquifers

\begin{tabular}{|c|c|c|c|c|c|c|c|c|}
\hline \multirow{2}{*}{ Aquifer group } & \multirow{2}{*}{ Area } & \multicolumn{6}{|c|}{ Concentration $(\mu \mathrm{g} / \mathrm{L})$} & \multirow[t]{2}{*}{\begin{tabular}{|l|} 
Reference \\
\end{tabular}} \\
\hline & & Min & Mean & Max & P50 & P95 & P97.7 & \\
\hline \multirow{2}{*}{ Quaternary } & Rheidol & $<20$ & 21 & 40 & 22 & & 38 & \multirow{2}{*}{ Shand et al. (2005) } \\
\hline & Teifi & 23 & 73 & 173 & 55 & & 164 & \\
\hline \multirow{10}{*}{ Chalk } & Yorkshire/Humber & $<20$ & 62 & 870 & $<100$ & & 130 & \multirow{10}{*}{$\begin{array}{l}\text { Smedley et al. (2004) } \\
\text { Ander et al. (2006) } \\
\text { Ander et al. (2004) } \\
\text { Shand et al. (2003b) } \\
\text { Smedley et al. (2003) } \\
\text { Stuart and Smedley (2009) } \\
\text { Edmunds et al. (2002) }\end{array}$} \\
\hline & $(Y / H$ confined $)$ & $<100$ & 220 & 820 & 200 & & 700 & \\
\hline & North Norfolk & 10 & 45 & 120 & 52.6 & 94 & 104 & \\
\hline & Great Ouse & $<10$ & $<100$ & 200 & $<10$ & 50 & 204 & \\
\hline & Colne/Lee & 42 & 85 & 211 & 78 & 97 & 211 & \\
\hline & (C/L confined $)$ & $<20$ & 27 & 107 & 10 & & 94 & \\
\hline & North Downs & $<10$ & & 129 & $<10$ & & 78 & \\
\hline & ( $N$ D confined) & $<500$ & 100 & 300 & 100 & & 270 & \\
\hline & Hampshire & 9 & 40 & 308 & 19 & 193 & & \\
\hline & Dorset & 10 & & 163 & 44 & 71 & 118 & \\
\hline \multirow{8}{*}{ Limestone } & Oxford \& Wilts Corallian & 10 & 20 & 100 & 20 & 44 & 80 & Cobbing et al. (2004) \\
\hline & $\begin{array}{l}\text { Vale of Pickering } \\
\text { Corallian }\end{array}$ & $<20$ & & 43 & & & & Bearcock et al. (2015) \\
\hline & Cotswolds & $<20$ & 20 & 120 & 20 & 40 & 100 & Neumann et al. (2003) \\
\hline & Lincolnshire & 10 & 66 & 1287 & 20 & 100 & 441 & \multirow{5}{*}{$\begin{array}{l}\text { Griffiths et al. (2006) } \\
\text { Bearcock and Smedley (2009) } \\
\text { Abesser et al. (2005b) } \\
\text { Abesser and Smedley (2008) }\end{array}$} \\
\hline & (Lincs confined) & 10 & 39 & 250 & 20 & & 169 & \\
\hline & Magnesian & 2 & 40.8 & 866 & 7 & 343 & & \\
\hline & Carboniferous Northern & $<20$ & 20 & 150 & $<20$ & 32 & 70 & \\
\hline & Carboniferous Derby & $<20$ & 370 & 160 & 31 & 74 & & \\
\hline \multirow{7}{*}{$\begin{array}{l}\text { Permo-Triassic } \\
\text { Sandstone }\end{array}$} & Vale of York & $<20$ & 50 & 299 & 27 & 84 & 280 & Shand et al. (2002) \\
\hline & Liverpool \& Rufford & 25 & 158 & 800 & 100 & 534 & 695 & Griffiths et al. (2005) \\
\hline & West Cheshire \& Wirral & $<20$ & 121 & 1200 & 64 & 250 & 446 & Griffiths et al. (2003a) \\
\hline & $\begin{array}{l}\text { Manchester \& East } \\
\text { Cheshire }\end{array}$ & $<20$ & 100 & 700 & 100 & 500 & 500 & Griffiths et al. (2003b) \\
\hline & South Staffordshire & $<20$ & 110 & 1130 & 50 & 160 & 530 & Tyler-Whittle et al. (2002) \\
\hline & Shropshire & $<20$ & 80 & 320 & 55 & 171 & 250 & Smedley et al. (2005) \\
\hline & Otter & $<10$ & 65 & 300 & 20 & 240 & & Bearcock and Smedley (2012) \\
\hline \multirow{4}{*}{ Devonian ORS } & South Wales \& Hereford & $<20$ & $<20$ & 75 & 20 & 44 & 70 & Moreau et al. (2004) \\
\hline & Moray Basin & $<20$ & & 172 & 36 & 127 & & Ó Dochartaigh et al. (2010) \\
\hline & Strathmore, Scotland & $<20$ & & 40500 & 30 & 50 & & Ó Dochartaigh et al. (2006) \\
\hline & Southern Scotland & 28 & & 152 & 45 & & & MacDonald et al. (2008) \\
\hline \multirow{6}{*}{ Other sandstone } & Crag & 10 & 99 & 922 & 163 & 92 & 723 & Ander et al. (2006) \\
\hline & Thames Palaeogene & $<10$ & 175 & 1400 & 41 & 961 & & Bearcock and Smedley (2010) \\
\hline & Wessex Palaeogene & $<20$ & 86.7 & 329 & 48 & 230 & 310 & Neumann et al. (2004) \\
\hline & Millstone Grit & $<20$ & $<20$ & 50 & 20 & 41 & 50 & Abesser et al. (2005a) \\
\hline & Lower Greensand & $<20$ & 70 & 311 & 32 & 200 & 301 & Shand et al. (2003a) \\
\hline & Bridport Sand & 10 & 100 & 300 & 80 & 100 & 190 & Shand et al. (2004) \\
\hline \multirow{2}{*}{ Carboniferous } & Midland Valley & $<20$ & & 432 & 7 & 125 & & Ó Dochartaigh et al. (2011) \\
\hline & Southern Scotland & $<20$ & & 680 & 27 & & & MacDonald et al. (2008) \\
\hline \multirow{2}{*}{$\begin{array}{l}\text { Dalradian and } \\
\text { igneous }\end{array}$} & Cornwall Granite & $<20$ & 90 & 900 & $<100$ & & 470 & Smedley and Allen (2004) \\
\hline & Aberdeenshire & $<20$ & & 138 & 40 & 104 & & Smedley et al. (2009) \\
\hline \multirow{6}{*}{ Palaeozoic } & Plynlimon Severn & 10 & 28.2 & 63 & 21 & & 62.2 & \multirow{6}{*}{ Shand et al. (2005) } \\
\hline & Plynlimon Wye & 10 & 63 & 330 & 10 & & 327 & \\
\hline & Teifi & 10 & 123 & 1670 & 45 & & 906 & \\
\hline & Rheidol & $<20$ & 21 & 40 & 22 & & 38 & \\
\hline & Silurian S Scotland & $<20$ & & 62 & 24.5 & & & \\
\hline & Ordovician S Scot & $<20$ & & 27 & 2.5 & & & \\
\hline
\end{tabular}


Table 5 Summary of baseline concentrations of DOC in groundwater. Data in italics for confined aquifers

\begin{tabular}{|c|c|c|c|c|c|c|c|c|}
\hline \multirow{2}{*}{ Aquifer group } & \multirow{2}{*}{ Area } & \multicolumn{6}{|c|}{ Concentration (mg/L) } & \multirow[t]{2}{*}{ Reference } \\
\hline & & Min & Mean & Max & P50 & P95 & P97.7 & \\
\hline Quaternary & Rheidol & 1.1 & 1.8 & 2.6 & 1.9 & & 2.5 & Shand et al. (2005) \\
\hline \multirow{9}{*}{ Chalk } & Yorkshire/Humber & 2.5 & 4.8 & 14 & 4.4 & & 8.6 & \multirow{2}{*}{ Smedley et al. (2004) } \\
\hline & $(Y / H$ confined $)$ & 6.1 & 8.1 & 11.6 & 7.3 & & 11.4 & \\
\hline & North Norfolk & 0.74 & 1.84 & 23.2 & 3.22 & 7.16 & 13.09 & Ander et al. (2006) \\
\hline & Great Ouse & 0.2 & 1.7 & 4.1 & 1.5 & 3.2 & 3.5 & Ander et al. (2004) \\
\hline & Colne/Lee & 1.15 & 1.86 & 3.09 & 1.66 & & 1.29 & Chond ot ol $(2002 \mathrm{~b})$ \\
\hline & (C/L confined $)$ & 1.29 & 3.17 & 7.29 & 2.34 & & 6.92 & Shana el al. (200so) \\
\hline & North Downs & $<0.6$ & & 4.6 & 1.4 & 3.5 & 4.1 & Smedley et al. (2003) \\
\hline & Hampshire & 0.46 & 0.813 & 1.24 & 0.8 & 1.1 & & Stuart and Smedley (2009) \\
\hline & Dorset & 0.25 & & 4.16 & 0.75 & 3.2 & 3.8 & Edmunds et al. (2002) \\
\hline \multirow{7}{*}{ Limestone } & Oxford \& Wilts Corallian & 0.4 & 1.78 & 8.7 & 1.2 & 3.2 & 5.84 & Cobbing et al. (2004) \\
\hline & Cotswolds & $<1$ & 2.52 & 5.4 & 2.1 & 5.1 & 5.21 & Neumann et al. (2003) \\
\hline & Lincolnshire & 1.64 & 2.98 & 5.47 & 2.9 & 4.66 & 5.1 & Criffithc ot al (2006) \\
\hline & (Lincs confined) & 1.28 & 3.26 & 6.15 & 3.03 & 5.3 & 5.76 & Grimitins et di. (2000) \\
\hline & Magnesian & 0.52 & 2.05 & 5.00 & 1.36 & 4.93 & & Bearcock and Smedley (2009) \\
\hline & CarboniferousNorthern & $<0.1$ & 1.655 & 5.51 & 0.98 & 4.3 & 4.56 & Abesser et al. (2005b) \\
\hline & Carboniferous Derby & 0.4 & 1.4 & 8.6 & 1.6 & & & Abesser and Smedley (2008) \\
\hline \multirow{8}{*}{$\begin{array}{l}\text { Permo-Triassic } \\
\text { Sandstone }\end{array}$} & Vale of York & 0.9 & 4.9 & 19.2 & 3 & 13.4 & 18.7 & Shand et al. (2002) \\
\hline & Liverpool \& Rufford & 2.6 & 8.5 & 17.5 & 9.2 & 15.3 & 16.7 & Griffiths et al. (2005) \\
\hline & West Cheshire \& Wirral & 1.7 & 3 & 5 & 2.6 & 4.8 & 5 & Griffiths et al. (2003a) \\
\hline & Manchester \& East & 01 & 15 & 67 & 11 & 51 & 64 & Griffiths at al $(2003 \mathrm{~h})$ \\
\hline & Cheshire & 0.1 & 1.0 & 0.1 & 1.1 & 3.1 & 0.4 & 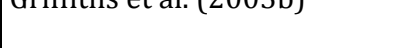 \\
\hline & South Staffordshire & 0.3 & 2.4 & 8.9 & 1.7 & 7.5 & 7.9 & Tyler-Whittle et al. (2002) \\
\hline & Shropshire & $<0.5$ & 1.1 & 4.8 & 0.8 & 2.5 & 3.7 & Smedley et al. (2005) \\
\hline & Otter & $<0.5$ & 1.16 & 6.48 & 0.594 & 3.7 & & Bearcock and Smedley (2012) \\
\hline \multirow{4}{*}{ Devonian ORS } & South Wales \& Hereford & 0.49 & 1.45 & 3.99 & 1.06 & 3.7 & 3.88 & Moreau et al. (2004) \\
\hline & Moray Basin & 0.44 & & 11.3 & 1.26 & 9.65 & & Ó Dochartaigh et al. (2010) \\
\hline & Strathmore Scotland & 0.38 & & 3.7 & 0.88 & 2.3 & & Ó Dochartaigh et al. (2006) \\
\hline & Southern Scotland & 0.27 & & 1.17 & 0.54 & & & MacDonald et al. (2008) \\
\hline \multirow{6}{*}{ Other sandstone } & Crag & 0.82 & 1.69 & 6.66 & 2.01 & & 5.39 & Ander et al. (2006) \\
\hline & Thames Palaeogene & 0.354 & 3.52 & 45.3 & 1.34 & 12.4 & & Bearcock and Smedley (2010) \\
\hline & Wessex Palaeogene & 0.4 & 1.82 & 8 & 1.1 & 7.1 & 7.75 & Neumann et al. (2004) \\
\hline & Lower Greensand & 0.74 & 3.6 & 2.7 & 10.1 & 9.3 & 9.7 & Abesser et al. (2005a) \\
\hline & Bridport Sand & 0.95 & 2.32 & 7.94 & 3.09 & 6.3 & 7.21 & Shand et al. (2003a) \\
\hline & Millstone Grit & $<0.1$ & 1 & 4.9 & 0.8 & 3.1 & 3.3 & Shand et al. (2004) \\
\hline \multirow{2}{*}{ Carboniferous } & Midland Valley & 0.45 & & 70.8 & 1.2 & 47.1 & & Ó Dochartaigh et al. (2011) \\
\hline & Southern Scotland & 1 & & 1.53 & 1.17 & & & MacDonald et al. (2008) \\
\hline Dalradian and & Cornwall Granite & 0.3 & 1.3 & 5.8 & 0.9 & & 4.2 & Smedley and Allen (2004) \\
\hline igneous & Aberdeenshire & 0.26 & & 7.44 & 1.34 & 5.62 & & Smedley et al. (2009) \\
\hline \multirow{4}{*}{ Palaeozoic } & Plynlimon Wye & 0.22 & 1.32 & 7.3 & 1.05 & & 5.15 & \multirow{4}{*}{ Shand et al. (2005) } \\
\hline & Rheidol & 0.8 & 3.6 & 11.3 & 2.5 & & 9.9 & \\
\hline & Silurian S Scotland & 0.45 & & 3.05 & 1.29 & & & \\
\hline & Ordovician S Scotland & 0.96 & & 3.74 & 2.21 & & & \\
\hline
\end{tabular}


Table 6 Summary of mean DOC concentrations selected for aquifers (from Rivett et al., 2007)

\begin{tabular}{|l|c|c|c|c|}
\hline Lithology & $\begin{array}{c}\text { Mean DOC } \\
\text { (mg/L) }\end{array}$ & $\begin{array}{c}\text { Mean Log } \\
\text { DoC (mg/L) }\end{array}$ & $\begin{array}{c}\text { Std dev Log } \\
\text { DOC (mg/L) }\end{array}$ & $\begin{array}{c}\text { Sample size } \\
\text { (n) }\end{array}$ \\
\hline Quaternary & 1.83 & 0.14 & 0.34 & 270 \\
\hline Chalk & 0.73 & -0.21 & 0.23 & 1725 \\
\hline Lower Cretaceous aquifers & 0.71 & -0.25 & 0.29 & 296 \\
\hline Jurassic Limestone & 0.94 & -0.093 & 0.23 & 833 \\
\hline Permo-Triassic sandstone & 1.39 & 0.0066 & 0.36 & 3415 \\
\hline Magnesian Limestone & 1.07 & -0.087 & 0.33 & 299 \\
\hline Coal Measures & 1.63 & 0.13 & 0.27 & 850 \\
\hline Millstone Grit & 1.45 & 0.024 & 0.33 & 897 \\
\hline Carboniferous limestone & 1.39 & 0.036 & 0.31 & 1453 \\
\hline
\end{tabular}




\section{Figures}

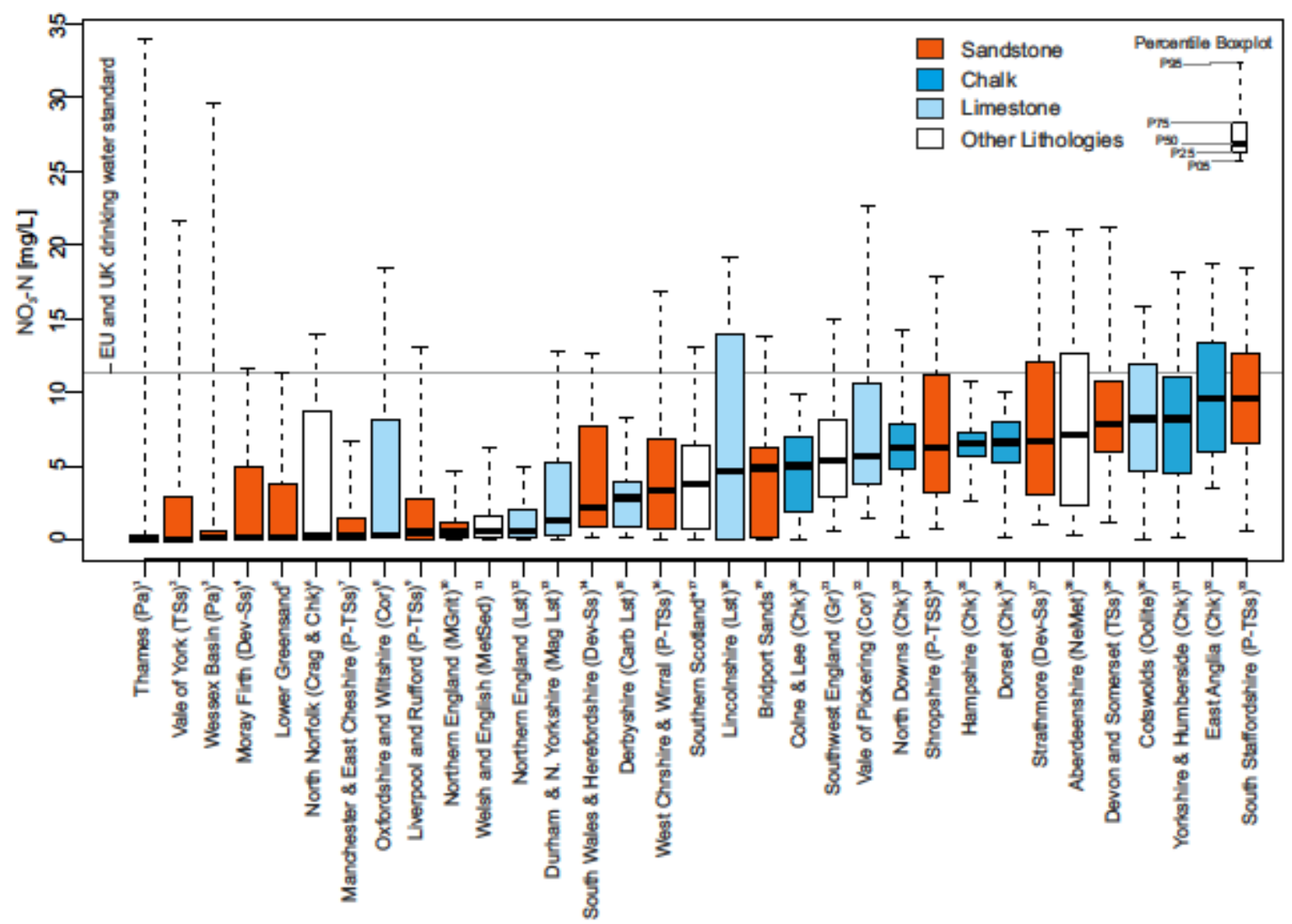

Figure 1 Boxplots of baseline nitrate-N concentrations for UK aquifers grouped by lithology. EU and UK drinking water standard is shown for comparison. Box colour: Orange - Sandstone and unconsolidated sand deposits; Cyan- Chalk; light blue -Limestone; white - other lithologies. Lithology: PTSs - Perm-Triassic Sandstone; Dev-Ss - Devonian Sandstone; Chk - Chalk; Lst - Limestone; Cor Corallian Limestone; MGrit - Millstone Grit; Gr - Granite; * - multiple lithologies; NeMet - Crystalline Neoproterozoic Metamorphic; Pa - Paleogene. Numbered references: 1 - Bearcock and Smedley (2010); 2 -Shand et al. (2002); 3 - Neumann et al. (2004); 4 - Ó Dochartaigh et al. (2010); 5 - Shand et al. (2003a); 6 Ander et al. (2006); 7 - Griffiths et al. (2003b); 8 - Cobbing et al. (2004); 9 - Griffiths et al. (2005); 10 Abesser et al. (2005a); 11 - Shand et al. (2005); 12 - Abesser et al. (2005b); 13 - Bearcock and Smedley (2009); 14 - Moreau et al. (2004); 15 - Smedley (2008); 16 - Griffiths et al. (2003a); 17 - MacDonald et al (2008); 18 - Griffiths et al. (2006); 19 - Shand et al. (2004); 20 - Shand et al. (2003b); 21 - Smedley and Allen (2004); 22 - Bearcock et al. (2015); 23 - Smedley et al. (2003); 24 - Smedley et al. (2005); 25 - Stuart and Smedley (2009); 26 - Edmunds et al. (2002); 27 - Ó Dochartaigh et al. (2006); 28 - Smedley et al. (2009); 29 - Bearcock and Smedley (2011); 30 - Neumann et al., (2003); 31 - Smedley et al. (2004); 32 Ander et al. (2004); 33 - Tyler-Whittle et al. (2002). 


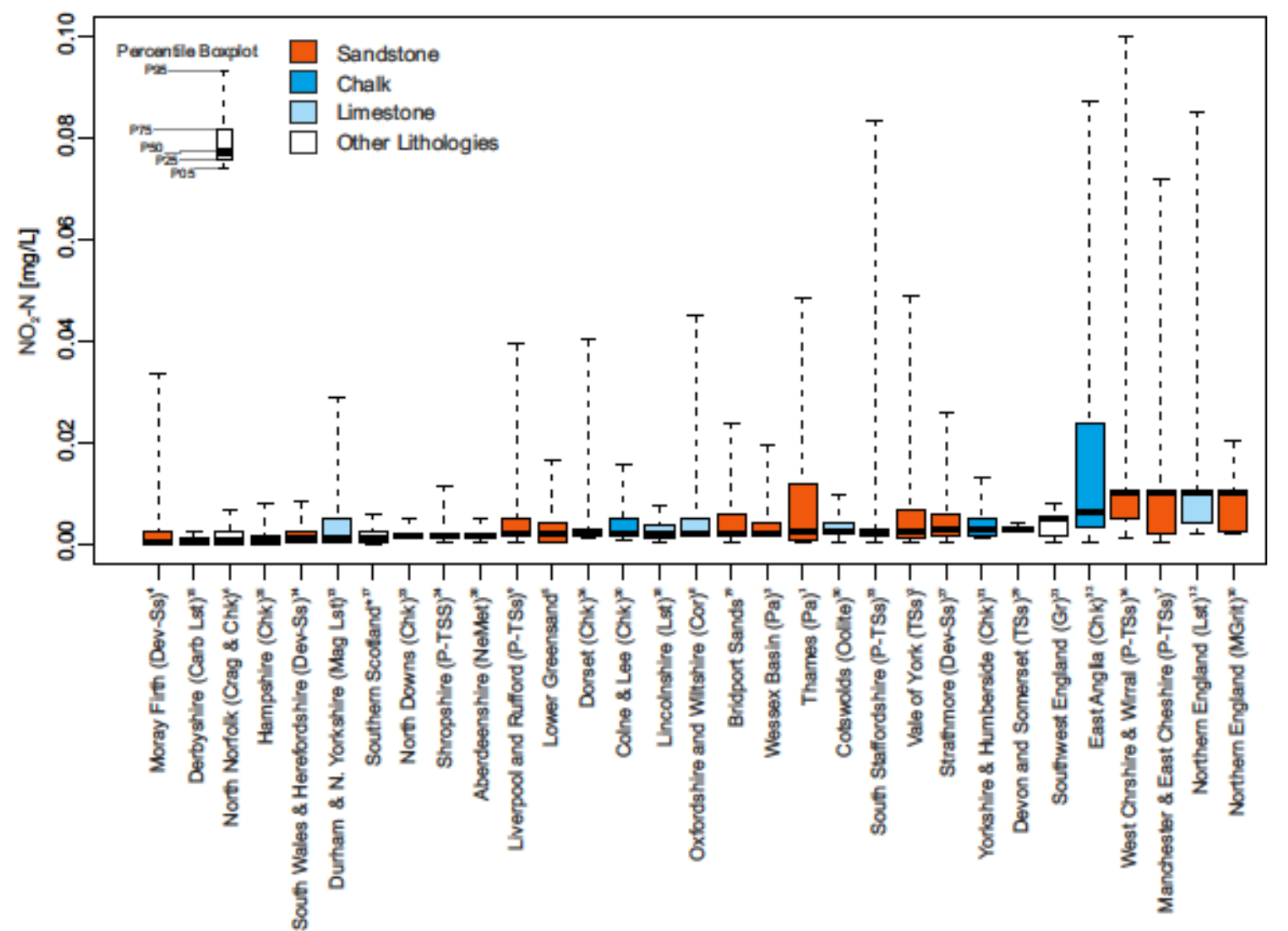

Figure 2 Boxplots of baseline nitrite-N concentrations for UK aquifers grouped by lithology. Box colour: Orange - Sandstone and unconsolidated sand deposits; Cyan- Chalk; light blue -Limestone; white other lithologies. Lithology: P-TSs - Perm-Triassic Sandstone; Dev-Ss - Devonian Sandstone; Chk - Chalk; Lst - Limestone; Cor - Corallian Limestone; MGrit - Millstone Grit; Gr - Granite; * - multiple lithologies; NeMet - Crystalline Neoproterozoic Metamorphic; Pa - Paleogene. Numbered references: 1 - Bearcock and Smedley (2010); 2 -Shand et al. (2002); 3 - Neumann et al. (2004); 4 - Ó Dochartaigh et al. (2010); 5 Shand et al. (2003a); 6 - Ander et al. (2006); 7 - Griffiths et al. (2003b); 8 - Cobbing et al. (2004); 9 Griffiths et al. (2005); 10 - Abesser et al. (2005a); 12 - Abesser et al. (2005b); 13 - Bearcock and Smedley (2009); 14 - Moreau et al. (2004); 15 - Smedley (2008); 16 - Griffiths et al. (2003a); 17 - MacDonald et al (2008); 18 - Griffiths et al. (2006); 19 - Shand et al. (2004); 20 - Shand et al. (2003b); 21 - Smedley and Allen (2004); 23 - Smedley et al. (2003); 24 - Smedley et al. (2005); 25 - Stuart and Smedley (2009); 26 Edmunds et al. (2002); 27 - Ó Dochartaigh et al. (2006); 28 - Smedley et al. (2009); 29 - Bearcock and Smedley (2011); 30 - Neumann et al., (2003); 31 - Smedley et al. (2004); 32 - Ander et al. (2004); 33 Tyler-Whittle et al. (2002). 


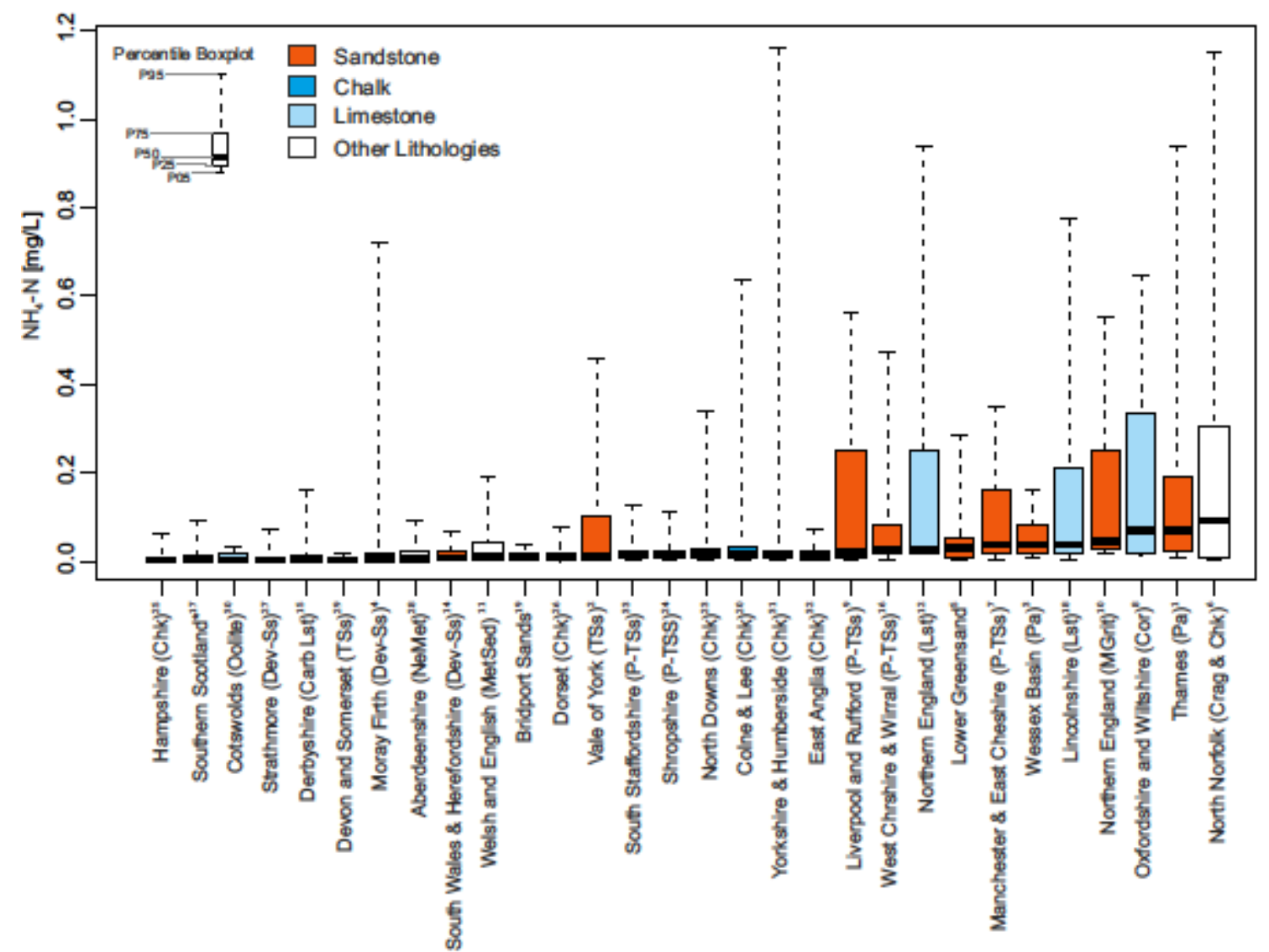

Figure 3 Boxplots of baseline ammonium- $\mathrm{N}$ concentrations for UK aquifers Orange - Sandstone and unconsolidated sand deposits; Cyan- Chalk; light blue -Limestone; white - other lithologies. Lithology: P-TSs - Perm-Triassic Sandstone; Dev-Ss - Devonian Sandstone; Chk - Chalk; Lst - Limestone; Cor Corallian Limestone; MGrit - Millstone Grit; Gr - Granite; * - multiple lithologies; NeMet - Crystalline Neoproterozoic Metamorphic; Pa - Paleogene. Numbered references: 1 - Bearcock and Smedley (2010); 2 -Shand et al. (2002); 3 - Neumann et al. (2004); 4 - Ó Dochartaigh et al. (2010); 5 - Shand et al. (2003a); 6 Ander et al. (2006); 7 - Griffiths et al. (2003b); 8 - Cobbing et al. (2004); 9 - Griffiths et al. (2005); 10 Abesser et al. (2005a); 12 - Abesser et al. (2005b); 13 - Bearcock and Smedley (2009); 14 - Moreau et al. (2004); 15 - Smedley (2008); 16 - Griffiths et al. (2003a); 17 - MacDonald et al (2008); 18 - Griffiths et al. (2006); 19 - Shand et al. (2004); 20 - Shand et al. (2003b); 21 - Smedley and Allen (2004); 23 - Smedley et al. (2003); 24 - Smedley et al. (2005); 25 - Stuart and Smedley (2009); 26 - Edmunds et al. (2002); 27 - Ó Dochartaigh et al. (2006); 28 - Smedley et al. (2009); 29 - Bearcock and Smedley (2011); 30 - Neumann et al., (2003); 31 - Smedley et al. (2004); 32 - Ander et al. (2004); 33 - Tyler-Whittle et al. (2002). 

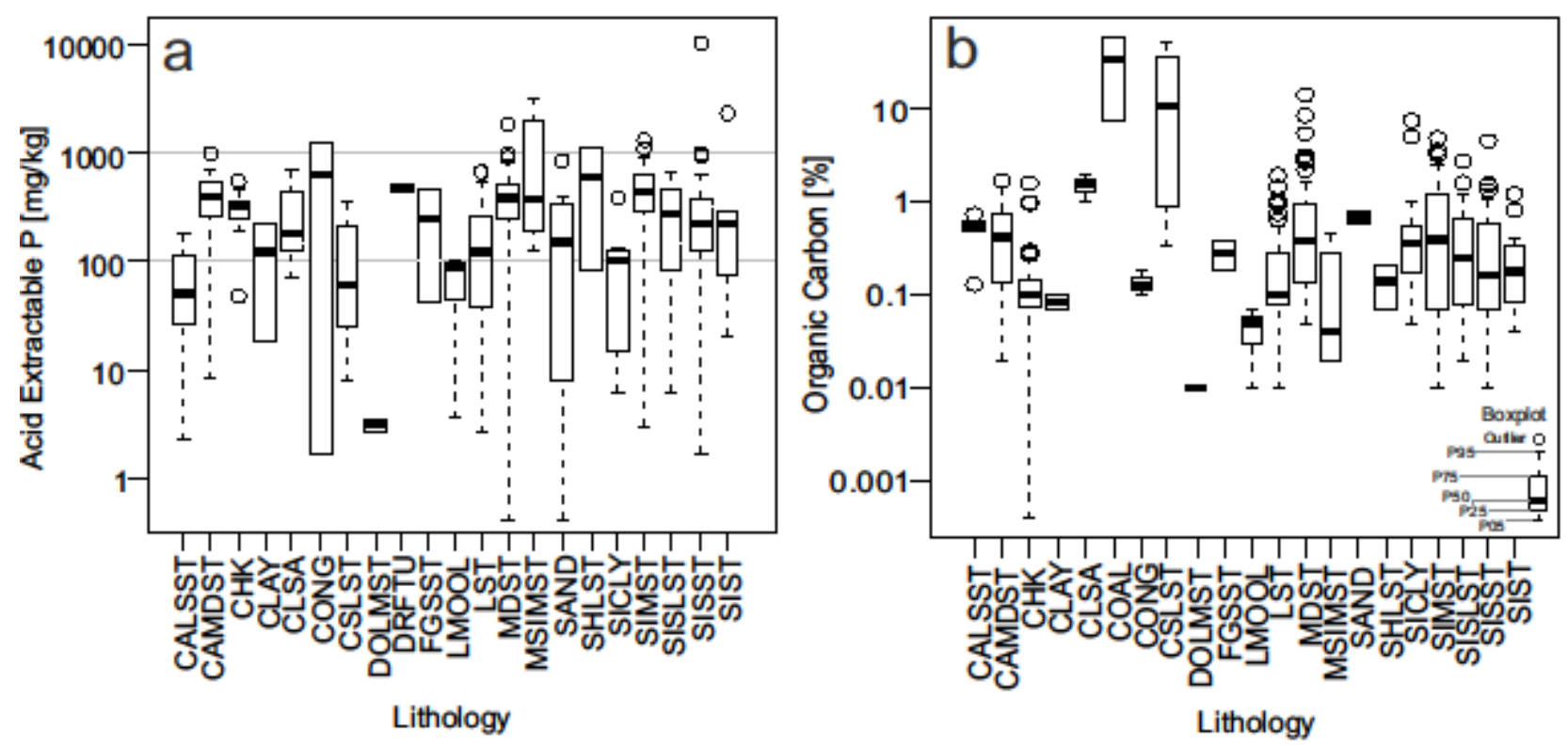

Figure 4 UK aquifer matrix geochemistry a) acid extractable P (mg/kg) by UK lithology. b) \% organic carbon. For data source and details on methods used see Milne and Kinniburgh (2006). Lithology codes: CALSST- Calcareous Sandstone; CAMDST - Calcareous Mudstone; CHK - Chalk; CLAY - Clay; CLSA Clayey Sand; CONG - Conglomerate; CSLST - Carbonaceous Siltstone ; DOLMST - Dolomitic Mudstone ; DRFTU - Drift deposits; FGSST - Ferruginous Sandstone; LMOOL - Ooid Limestone ; LST - Limestone ; MDST - Mudstone ; MSIMST - Metasilicate Mudstone ; SAND - Sand formations ; SHLST - Shell Limestone ; SICLY - Silicate Clay ; SIMST - Silicate Mudstone ; SISLST - Silicate Siltstone; SISST - Silicate Sandstone ; SIST - Silicate Sand. Important aquifers coloured Chalk-blue; Ooid limestone- green; Silicate sandstonebrown 


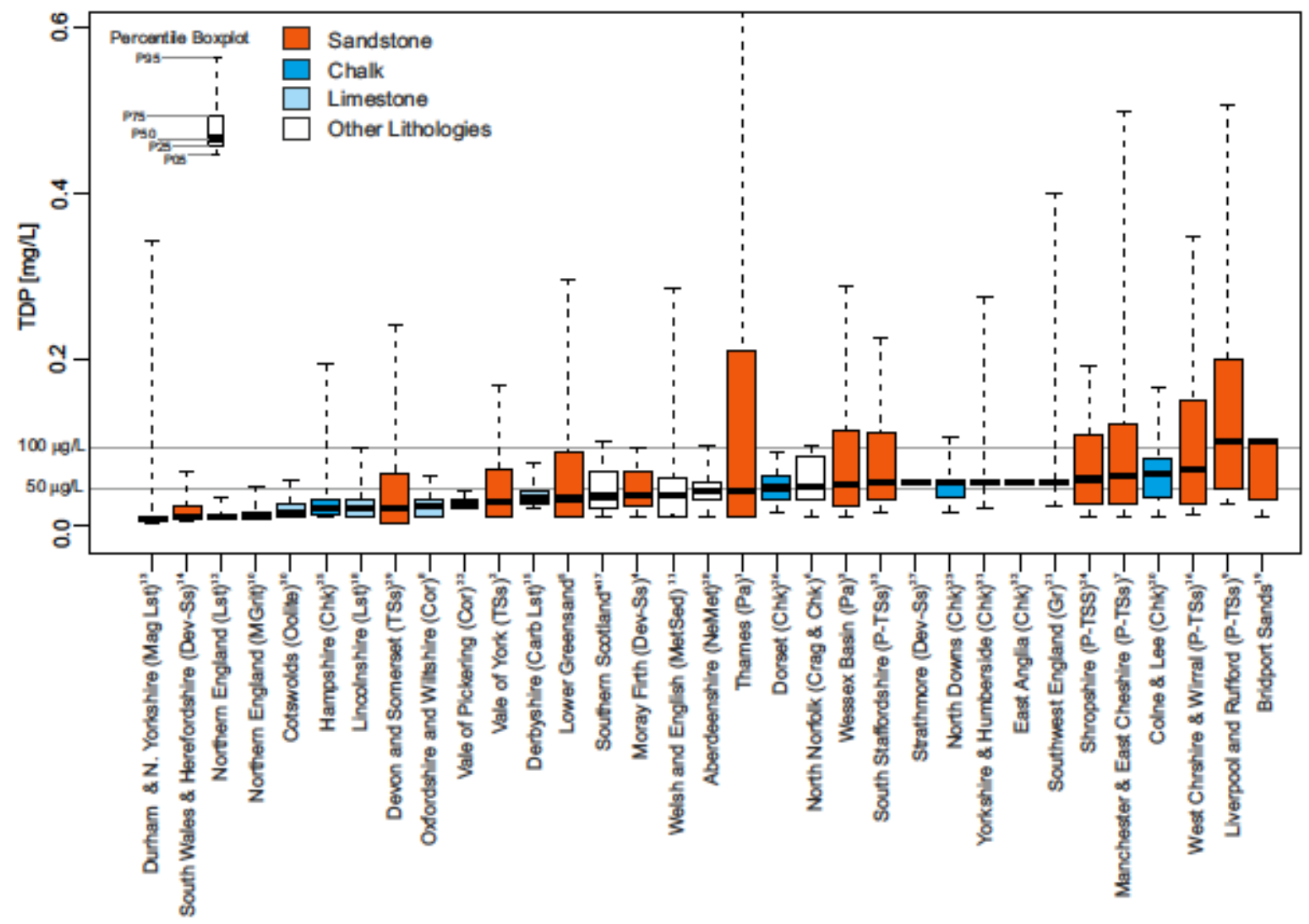

Figure 5 Boxplots of baseline TDP concentrations in UK aquifers) grouped by lithology. Horizontal lines showing $100 \mu \mathrm{g} / \mathrm{L}$ and $50 \mu \mathrm{g} / \mathrm{L}$ TDP concentrations for comparison. Box colour: Orange - Sandstone and unconsolidated sand deposits; Cyan- Chalk; light blue -Limestone; white - other lithologies. Lithology: P-TSs - Perm-Triassic Sandstone; Dev-Ss - Devonian Sandstone; Chk - Chalk; Lst - Limestone; Cor Corallian Limestone; MGrit - Millstone Grit; Gr - Granite; * - multiple lithologies; NeMet - Crystalline Neoproterozoic Metamorphic; Pa - Paleogene. 1 - Bearcock and Smedley (2010); 2 -Shand et al. (2002); 3 Neumann et al. (2004); 4 - Ó Dochartaigh et al. (2010); 5 - Shand et al. (2003a); 6 - Ander et al. (2006); 7 Griffiths et al. (2003b); 8 - Cobbing et al. (2004); 9 - Griffiths et al. (2005); 10 - Abesser et al. (2005a); 11 Shand et al. (2005); 12 - Abesser et al. (2005b); 13 - Bearcock and Smedley (2009); 14 - Moreau et al. (2004); 15 - Smedley (2008); 16 - Griffiths et al. (2003a); 17 - MacDonald et al (2008); 18 - Griffiths et al. (2006); 19 - Shand et al. (2004); 20 - Shand et al. (2003b); 21 - Smedley and Allen (2004); 22 - Bearcock et al. (2015); 23 - Smedley et al. (2003); 24 - Smedley et al. (2005); 25 - Stuart and Smedley (2009); 26 Edmunds et al. (2002); 27 - Ó Dochartaigh et al. (2006); 28 - Smedley et al. (2009); 29 - Bearcock and Smedley (2011); 30 - Neumann et al., (2003); 31 - Smedley et al. (2004); 32 - Ander et al. (2004); 33 - TylerWhittle et al. (2002). 


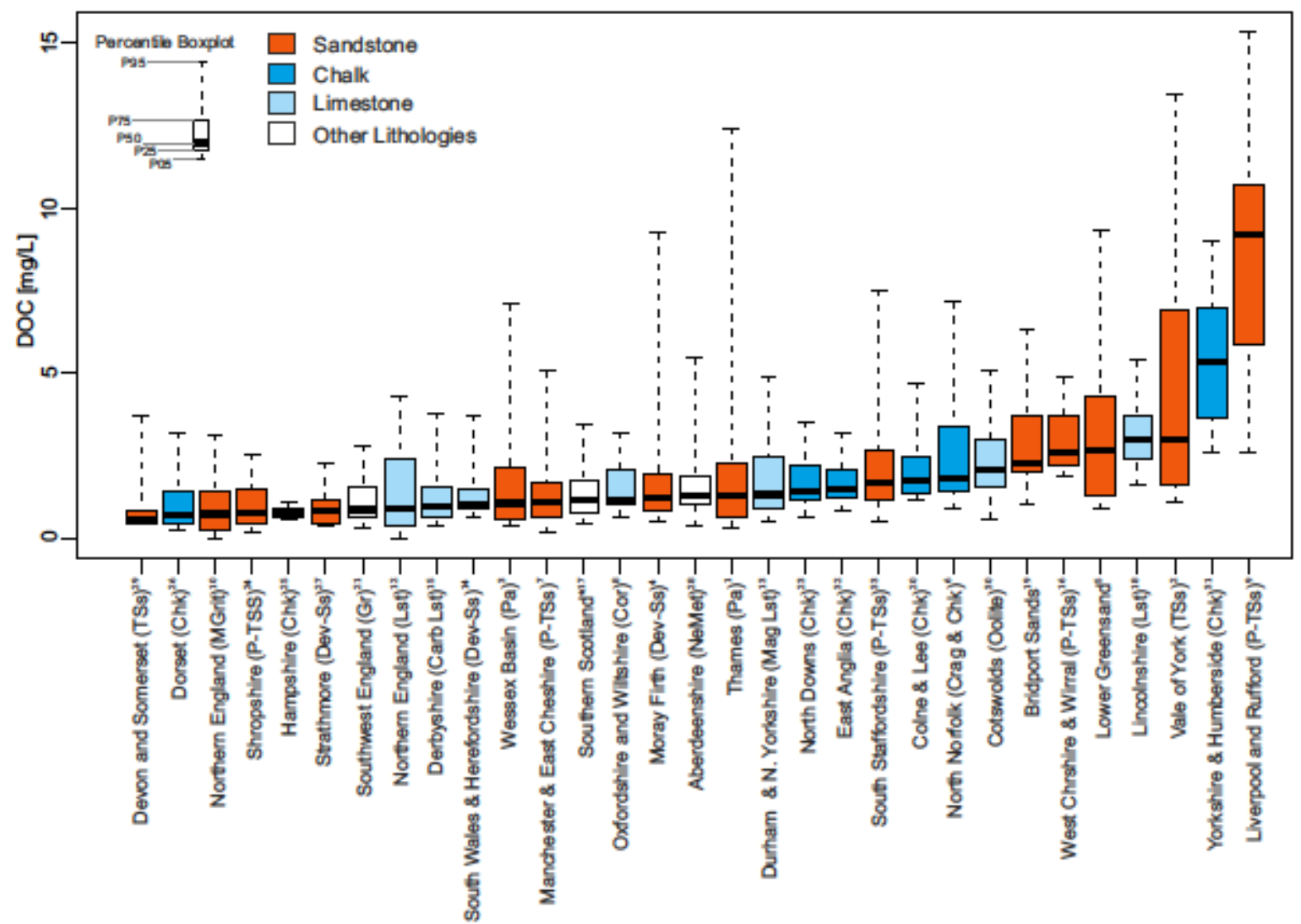

Figure 6 Boxplots of baseline DOC concentrations in UK aquifers grouped by lithology. Box colour: Orange - Sandstone and unconsolidated sand deposits; Cyan- Chalk; light blue -Limestone; white - other lithologies. Lithology: P-TSs - Perm-Triassic Sandstone; Dev-Ss - Devonian Sandstone; Chk - Chalk; Lst Limestone; Cor - Corallian Limestone; MGrit - Millstone Grit; Gr - Granite; * - multiple lithologies; NeMet - Crystalline Neoproterozoic Metamorphic; Pa - Paleogene. 1 - Bearcock and Smedley (2010); 2 -Shand et al. (2002); 3 - Neumann et al. (2004); 4 - Ó Dochartaigh et al. (2010); 5 - Shand et al. (2003a); 6 - Ander et al. (2006); 7 - Griffiths et al. (2003b); 8 - Cobbing et al. (2004); 9 - Griffiths et al. (2005); 10 - Abesser et al. (2005a); 12 - Abesser et al. (2005b); 13 - Bearcock and Smedley (2009); 14 - Moreau et al. (2004); 15 Smedley (2008); 16 - Griffiths et al. (2003a); 17 - MacDonald et al (2008); 18 - Griffiths et al. (2006); 19 Shand et al. (2004); 20 - Shand et al. (2003b); 21 - Smedley and Allen (2004); 23 - Smedley et al. (2003); 24 - Smedley et al. (2005); 25 - Stuart and Smedley (2009); 26 - Edmunds et al. (2002); 27 - Ó Dochartaigh et al. (2006); 28 - Smedley et al. (2009); 29 - Bearcock and Smedley (2011); 30 - Neumann et al., (2003); 31 - Smedley et al. (2004); 32 - Ander et al. (2004); 33 - Tyler-Whittle et al. (2002). 